\title{
Simulating ungulate herbivory across forest landscapes: a browsing extension for LANDIS-II
}

Nathan R. De Jager ${ }^{1}$, Patrick J. Drohan ${ }^{2}$, Brian M. Miranda ${ }^{3}$, Brian R. Sturtevant ${ }^{3}$, Susan L. Stout ${ }^{4}$, Alejandro A. Royo ${ }^{4}$, Eric J. Gustafson ${ }^{3}$, Mark C. Romanski ${ }^{5}$

${ }^{1}$ U.S. Geological Survey Upper Midwest Environmental Sciences Center, La Crosse, WI 54603

${ }^{2}$ The Pennsylvania State University, University Park, PA 16802

${ }^{3}$ USDA Forest Service Northern Research Station, Rhinelander, WI 54501

${ }^{4}$ USDA Forest Service Northern Research Station, Irvine, PA 16329

${ }^{5}$ Isle Royale National Park, Houghton, MI, 49931

Corresponding author: Dr Nathan R. De Jager

U.S. Geological Survey Upper Midwest Environmental Sciences Center

La Crosse 54603

United States

E-mail: ndejager@usgs.gov

(C) 2016. This manuscript version is made available under the Elsevier user license http://www.elsevier.com/open-access/userlicense/1.0/ 


\begin{abstract}
Browsing ungulates alter forest productivity and vegetation succession through selective foraging on species that often dominate early succession. However, the long-term and large-scale effects of browsing on forest succession are not possible to project without the use of simulation models. To explore the effects of ungulates on succession in a spatially explicit manner, we developed a Browse Extension that simulates the effects of browsing ungulates on the growth and survival of plant species cohorts within the LANDISII spatially dynamic forest landscape simulation model framework. We demonstrate the capabilities of the new extension and explore the spatial effects of ungulates on forest composition and dynamics using two case studies. The first case study examined the long-term effects of persistently high white-tailed deer browsing rates in the northern hardwood forests of the Allegheny National Forest, USA. In the second case study, we incorporated a dynamic ungulate population model to simulate interactions between the moose population and boreal forest landscape of Isle Royale National Park, USA. In both model applications, browsing reduced total aboveground live biomass and caused shifts in forest composition. Simulations that
\end{abstract}


included effects of browsing resulted in successional patterns that were more similar to those observed in the study regions compared to simulations that did not incorporate browsing effects. Further, model estimates of moose population density and available forage biomass were similar to previously published field estimates at Isle Royale and in other moose-boreal forest systems. Our simulations suggest that neglecting effects of browsing when modeling forest succession in ecosystems known to be influenced by ungulates may result in flawed predictions of aboveground biomass and tree species composition.

Keywords: Allegheny National Forest, Deer, Isle Royale National Park, LANDIS-II, Moose, Population Dynamics, Simulation Model, Succession

\section{Introduction}

Browsing ungulates (e.g., moose and white-tailed deer) can modify plant growth and survival, successional trajectories, soil properties, nutrient cycles, and fire regimes (Hobbs, 1996; Healy, 1997; Rooney and Waller, 2003; Horsley et al., 2003; Danell et al., 2006). The magnitude and extent of their effects are determined by the intensity of browsing pressure relative to the amount and distribution of forage resources available in a landscape (de Calesta and Stout, 1997; Rooney et al., 2015), the selectivity of the ungulate population for specific plant species (Pastor and Cohen, 1997), and how different plant species respond to the loss of photosynthetic tissue (Danell et al., 1994; Skarpe and Hester, 2008).

Ungulates both affect and are affected by available plant biomass within their reach. These animals require large amounts of plant tissue to meet their daily energy requirements. For example, estimates of dry matter intake can be near $5 \mathrm{~kg}$ per day for white tailed deer (Odocoileus virginiana) (Ullrey et al., 1970) and as high as $10 \mathrm{~kg}$ per day for moose (Alces alces) (Persson et al., 2000). Although most browsing ungulates are commonly referred to as 'generalists', the majority of the biomass they consume each year 
comes from a handful of highly preferred woody, and often early successional plant species (Shipley et al., 2009). The large amount of biomass removed from plants by ungulates influences plant growth and survival, particularly of preferred plants (Danell et al., 1994; Russell et al., 2001). Where browsing alters growth and survival, less preferred species that remain unbrowsed or weakly browsed often win in bouts of competition, causing changes to the rate and trajectory of forest succession (Pastor and Naiman, 1992; Horsley et al., 2003; Rooney and Waller, 2003; Tripler et al., 2005; Krueger et al., 2009; Eschtruth and Battles, 2008; Nuttle et al., 2013).

Browsing ungulates inhabit a diverse array of forest ecosystems and are subject to varying degrees of management. Some wild populations are sustained at very high densities (e.g., white-tailed deer in North America) due to the loss of top-predators, the increased availability of alternative (non-forest) food resources, and population management strategies that were insensitive to habitat impacts (Alverson et al., 1988; Mysterud, 2006; Carson et al., 2014). Such persistently high populations can cause long-lasting effects on forest succession and composition, and thereby alter habitat suitability of landscapes for a widerange of animal species (deGraaf et al., 1991; deCalesta, 1994; Russell et al., 2001; Rooney and Waller, 2003; Nuttle et al., 2011; Coté et al., 2014). Other ungulate populations are managed to support objectives related to forest diversity and sustainability, while also providing hunting opportunities (Angelstam et al., 2000). In yet other systems, ungulate populations interact dynamically with food resources, predators, and other disturbances that influence the composition and structure of forests (e.g., fire, wind, and insect outbreaks) (Peterson et al., 2014). Finally, browsing impacts are not limited to wild ungulates. For example, browsing by domestic goats is known to have comparable magnitude of effects on forest composition and successional trajectories (Zamora et al., 2001). Given the wide range of ecosystems that browsing ungulates inhabit and varying degrees of population management that they experience, it is important to understand the dynamics of forest-ungulate interactions in the context of management actions and other processes that influence both population dynamics and forest succession. 
Simulation modeling offers a useful way to examine the complexities of plant-animal interactions within the context of other spatially explicit processes. A number of spatially explicit models have been developed to address the roles ungulates play in landscape-scale vegetation dynamics and to address questions about how landscape patterns influence ungulate movement and population dynamics (e.g., Moen et al., 1997, 1998; van Oene et al., 1999; Kramer et al., 2001, 2003; Coughenour, 2002; Forsyth et al., 2015; Riggs et al. 2015). For a thorough review of some of these models, see Weisberg et al. (2006). Some models capture vegetation processes and the effects of herbivory on plant growth and survival, but over-simplify animal foraging behavior and population dynamics. Other models focus on animal dispersal, foraging mechanics, energetics and/or population dynamics but over-simplify vegetation dynamics and the effect herbivory can have on them. Furthermore, each model was developed to represent particular ecosystems or phenomena (e.g., herbivory by fire interactions, Riggs et al. 2015) which sometimes operate over a limited range of spatial and temporal scales. There remains a need for a linked plant-herbivore ecosystem model that can forecast effects of succession in a broad range of forest ecosystems, and address critical ecological questions and management scenarios - ideally, one that is embedded within a modeling framework that can account for interactions with other critical processes affecting forest dynamics in time and space.

In this paper, we describe a new browse extension for the forest landscape simulation model, LANDISII (Scheller et al., 2007). The extension uses the biomass associated with annual net primary productivity as a common currency linking tree species cohort growth, ungulate populations, and browsing impacts. Our aim was to develop an extension with a degree of complexity and flexibility comparable to that of other LANDIS-II extensions (such as those representing wind, fire, insects, and harvesting), enabling the modeling system to represent ungulate browsing processes and consequences at broad spatial and temporal scales. This paper introduces the extension within the framework of LANDIS-II and demonstrates adaptability of the extension to address effects of browsing via two case study applications. The first examines effects of browsing by white-tailed deer on aboveground biomass and forest succession in a 
northern hardwood forest (Allegheny National Forest, USA, Fig. 1) with persistently high rates of browsing. The second case study examines interactions between a moose population and spatial patterns of available forage biomass and associated impacts on forest succession in a boreal landscape (Isle Royale National Park, Michigan, USA, Fig. 1). Our primary question is whether incorporating effects of browsing in these two landscapes results in different model estimates of forest biomass, composition, and successional trajectories.

\section{Methods}

\subsection{LANDIS-II}

LANDIS-II (Scheller et al., 2007) is a process-based forest landscape disturbance and succession model that simulates the forest generative processes of dispersal, establishment, growth and competition, and the forest degenerative processes of senescence and disturbances, such as insects and timber harvesting, at large spatial scales (>1,000 ha) and long temporal scales (centuries) (Mladenoff et al., 1993; Mladenoff and He, 1999) The Browse extension is currently designed to work with succession extensions that track biomass (e.g., Biomass Succession, Scheller and Mladenoff, 2004), which simulate the processes of establishment, growth, competition and senescence as they affect the biomass of cohorts of species on a collection of landscape sites (grid cells) of user defined size, typically from $30 \mathrm{~m}^{2}$ to $1 \mathrm{~km}^{2}$. The succession extension simulates the processes of species establishment (propagule arrival and the establishment of a viable cohort), competition for growing space and senescence, based on life history attributes of the taxa. Additional details on the Biomass Succession extension, as well as calibration data may be found in Scheller and Mladenoff (2004) and for v. 3.2 which is applied here, Scheller and Miranda (2015). Other processes that kill cohorts or remove some of their biomass can be simulated by other independent disturbance extensions. The Browse Extension, introduced below, functions within the LANDIS-II framework as a 
disturbance extension, in that it impacts tree species cohorts through biomass removal, growth reduction, and mortality within cells in the landscape.

\subsection{Browse Extension}

In this extension, ungulate browse pressure is defined for population regions (zones) within the landscape, either externally as a browser density index (BDI) or internally as a dynamic browser population (DBP). The externally defined BDI should be used when simulating a relatively constant population density that does not respond to changes in forest resources, such as might be the case with heavily managed ungulate populations or where alternative forage resources maintain persistently high populations (e.g., agricultural areas). The BDI would also be useful in more theoretical simulations where isolating the effects of alternative constant browsing pressures is the study aim. The internally defined (DBP) should be used when simulating a population that responds to changes in forage availability brought about by any factor that influences forest growth (including past browsing).

Browsing by free ranging ungulates is often conceptualized as a series of decisions and processes nested in a hierarchy (Senft et al., 1987). Tree species dynamics at the site (cell) scale, combined with functions defining browse accessibility and selective preference by the browsing ungulate define the amount and quality of browse on a given site. Intermediate to these two scales, neighborhood functions, typically at the scale of an ungulate home range, define how population density and browsing intensity (i.e., biomass consumed/removed) are distributed across a given population zone. Once browsing intensity is distributed across the simulated landscape, forage biomass is removed from sites in proportion to the browse pressure, defined either externally (BDI) or internally (DBP), and according to user-defined species preferences and target removal rates derived from the literature. Finally, herbivory influences the growth and development of browsed cohorts via the direct removal of biomass and additionally through userdefined species-specific growth response parameters. The sequence of model operations is shown in Fig. 2 
and a complete list of user-defined model parameter estimates is provided in Table 1. Below, we describe how various parameters and model operations function within the Browse Extension, but a more complete description of the model, including all equations, can be found in the User Guide (https://sites.google.com/site/landismodel/extensions/browse-disturbance).

\subsubsection{Available Forage Biomass}

At the start of each annual time step, the proportion of new growth which is both in the diet and within the reach of the herbivore is calculated for each species-cohort on each site. Within the extension, estimates of available forage biomass are summed on an annual basis and used to link forest growth, the browser population, and browsing effects. Because the Biomass Succession extension does not simulate plant height, we developed five parameter estimates to derive and calibrate available forage biomass from annual net primary productivity (ANPP). First, most studies estimate available forage biomass as the current annual growth of leaves and twigs accessible to foraging herbivores (Risenhoover, 1987; Persson et al., 2005; Butler and Kielland, 2008). We start by representing this with the parameter ANPPForageProp (Table 1), which is the proportion of ANPP that is leaves and twigs. Next, we use cohort biomass as a surrogate for height to determine which cohorts have ANPPForageProp within the height reach of the herbivore, under the assumption that established cohorts are "fully stocked" with respect to the available growing space in a cell (i.e., tree density is consistent). A cohort begins to escape the height reach of the herbivore at a userdefined proportion of the maximum biomass a site can support (BrowseBiomassThreshold, Table 1). The proportion of a cohort's biomass that is at or below this biomass threshold is within browse reach and constitutes available forage biomass. We further assumed that apical dominance within low-statured cohorts would drive susceptibility to browsing and that browsing of lower branches would be compensated for by growth beyond the browse line (McLaren and Peterson, 1994; Vila et al., 2002). Hence, cohorts with less than a user-defined proportion of their forage biomass within browse reach (MinBrowsePropinReach, Table 1) are assumed to have 'escaped' browsing and are therefore not included in estimates of available 
forage biomass. According to these functions, any factor that reduces the growth of cohorts serves to prolong the period of time that they provide available forage biomass and are susceptible to browsing. Next, we further ensured that senescing mature cohorts with declining biomass could not re-enter the available forage biomass pool by establishing an age threshold (EscapeBrowsePropLong, Table 1). Finally, in some systems, first-year cohorts may not be accessible to herbivores, especially in systems with deep snow cover during the winter and tall herbivores (e.g., moose). For this reason, users can choose not to use the initial biomass estimates associated with an establishing cohort to be available immediately after establishment (UseInitBiomassAsForage, Table 1).

\subsubsection{Site Preference}

The quality of available forage biomass at a site is based on user-defined species-specific preference values (SpeciesPreference, Tables 1 and 2). These preference values are defined as the fraction of available forage biomass that ungulates are expected to remove from a given species and they can be derived from the literature for many plant and ungulate species (e.g., Healy, 1971; Risenhoover, 1987; Hewitt, 2011). However, the actual amount of biomass removed from species varies spatially and temporally in accordance with animal population density and distribution (see Forage Biomass Consumption 2.2.6). At each timestep a map of site preference is produced by calculating the available forage biomass-weighted average preference value for each site (SitePreference, Table 1). Because the presence of non-forage species could influence the preference of herbivores for sites (Bee et al., 2009), users can optionally include non-forage species (preference $=0$ ) in calculations of site preference (CountNonForageSitePref, Table 1). 


\subsubsection{Habitat Suitability}

At each time step, the quantity and quality of available forage in the neighborhood of individual sites (cells) are used to distribute browsing impacts by estimating a habitat suitability index (HSI). Neighborhood effects are implemented by calculating moving window averages with user-defined window sizes. Habitat suitability can be based solely on a moving window average of forage quality (SitePreference), available forage biomass (ForageQuantity), or the product of the two (Table 1, Fig. 3). At each time step, a map of HSI is produced and used to calculate the local population density (when defined internally, DBP) or site browsing rate (when defined externally, SBI) and subsequent browse impact (Fig. 3, see details below). While the approach allows the flexibility to include other habitat factors affecting suitability (e.g., thermal cover, road density, proximity to water, alternative habitats or food sources, etc.), these other habitat features are not yet explicitly incorporated.

\subsubsection{Browser Density Index}

When externally defining a population, users must supply a Browser Density Index (BDI), which varies between 0 and 1 , and represents the ungulate population density relative to the capacity of the landscape or population zone to support it. Input maps may optionally define different zones $(Z)$ with independent values of the BDI, representing spatial variation in the density index, as might occur due to different population management zones. BDI values for each zone can vary through time within a simulation, but must be predefined by the user and do not respond dynamically to landscape changes. Site-level browse impacts $\left(\mathrm{SBI}_{\mathrm{S}}\right)$ are downscaled from the zone or landscape level browser index (BDI) to reflect spatial variation in forage quantity and habitat suitability at the site scale according to the following equation:

$$
S B I_{S}=\sum B D I_{Z} \times\left[\left(\frac{\text { ForageQuantity }_{S}}{\text { ForageQuantity }_{Z}} \times B D I_{Z}\right)+\left(\frac{H S I_{S}}{H S I_{Z}} \times\left(B D I_{Z}-1\right)\right)\right]
$$


Where $S B I_{S}$ is the site-level browse removal rate, $B D I_{Z}$ is the browser density index for zone $Z$, ForageQuantitys is the site-level forage quantity, ForageQuantity $\mathrm{z}$ is the total forage quantity summed within a zone, $\mathrm{HSI}_{S}$ is the site-level habitat suitability index, and $\mathrm{HSI}_{Z}$ is the sum of habitat suitability indices within a zone. This equation describes a decreasing influence of habitat suitability and increasing influence of forage quantity as BDI approaches 1 (100\% forage biomass removal). In other words, the population is allowed to be more selective and target sites of high habitat suitability when it is far from the capacity of the landscape to support it. However, as the browsing index approaches 1, its distribution must match that of forage availability (quantity) or it would not be possible to remove 100\% of available forage biomass. This concept may reflect the notion that herbivores can adjust their foraging behavior in proportion to variation in dietary reward and thus 'match' the distribution of food resources (Senft et al., 1987), depending on the ratio of population size to carrying capacity.

\subsubsection{Dynamic Browser Population}

When simulating an internally defined population, which responds dynamically to forage availability (DBP, dynamic browser population), temporal changes in the ungulate population are characterized by the discrete time quadratic model for logistic growth (May, 1975):

$\Delta N_{z}=R_{Z} N_{z}\left(1-\frac{N_{z}}{K_{z}}\right)$

Eq. 2

where $\Delta N_{z}$ is the change in population (\#) within zone $z ; R_{z}$ is the intrinsic rate of population growth (births - deaths) in zone $z ; N_{Z}$ is the total population (DBP) within zone $z$ and $K_{z}$ is the carrying capacity (nontrivial (non-zero) equilibrium population) within zone $z$. This model is useful because $K$ serves as an attractor for the ungulate population. As $N$ approaches $K, \Delta N$ goes to 0 . When $N<K$, recruitment exceeds mortality and the population increases. When $N>K$, mortality exceeds recruitment and the population declines. Carrying capacity is thus the population size at which density dependent factors balance 
reproduction and mortality (Begon et al., 1996). More specifically, we quantified carrying capacity as the maximum number of animals that can be supported by the forage biomass available within the landscape or zone at a given time, based on the annual intake rate of an average animal from the population (ConsumptionRate, Table 1). This method allows the carrying capacity of the population to emerge from all processes that regulate plant growth and forage production across the landscape and to vary from one time step to the next. Additional density independent factors that affect animal survival due to: a) harvesting (population management), b) predation, and c) other random factors can also be incorporated and change Eq. 2 to:

$\Delta N_{z}=R_{z} N_{z}\left(1-\frac{N_{z}}{K_{z}}\right)-H_{z} N_{z}-P_{z} N_{z}-M_{z} N_{z} \quad$ Eq. 3

Where $H_{z}$ is the zone specific mortality rate due to harvesting, $P_{z}$ is the zone specific predation rate, and $M_{z}$ is the zone specific mortality rate for random factors. At each time step, each of these parameters, as well as the population growth rate $(R)$, can be randomly generated between user-defined minimum and maximum estimates to incorporate stochasticity in the modeled population. While the approach allows the flexibility to include additional feedbacks among the population growth rate, population size, and other sources of animal mortality, these features are not yet implemented.

Similarly to how BDI is downscaled to sites when using the non-dynamic population, the dynamic population (DBP) is distributed to sites based on site-level forage quantity and habitat suitability, weighted by the proximity of the population to carrying capacity $(\mathrm{K})$ :

$N_{S}=N_{z}\left[\left(\frac{\text { ForageQuantity }}{\text { ForageQuantity }} \times \frac{N_{Z}}{K_{Z}}\right)+\left(\frac{H S I_{S}}{H S I_{Z}} \times\left(\frac{N_{Z}}{K_{Z}}\right)-1\right)\right] \quad$ Eq. 4

Where $N_{S}$ is the site-level population used to determine site-level browse impacts. This equation characterizes a decreasing importance of habitat suitability and increasing importance of forage quantity as the ungulate population approaches $K$, allowing the distribution of the population to match that of forage availability as the population reaches $K$. 


\subsubsection{Forage Biomass Consumption}

The total forage removed from sites is determined by the site population $\left(N_{S}\right)$ or the site browse index (SBI; if using non-dynamic population). The total forage to be removed (consumed) for a dynamic population is the site population multiplied by the ConsumptionRate (Table 1). For a non-dynamic population, the SBI serves as the proportion of available forage biomass to be removed. Within a site, species are rank-ordered by their preference values (SpeciesPreference, Table 1). These preference values not only rank species but define a target removal rate, which can be thought of as the fraction of available forage biomass that the ungulate population typically removes from a given species. Forage biomass is then removed from cohorts in proportion to their target removal rate up to the amount of forage to be consumed. If necessary, browsing continues beyond target removal rates, in rank order of preference, until the forage consumption amount is reached. This foraging process is analogous to a fractional foraging strategy (Moen et al., 1997) and allows the annual and local diet composition of the ungulate population to change over time in response to the abundance and distribution of preferred plant species and the forage requirements of the population, in contrast to setting a pre-defined diet composition.

\subsubsection{Effects of browsing on cohort growth and mortality}

Browsing is known to impact the growth of woody plants (Pastor and Danell, 2003) and many species display threshold or non-linear growth responses to increasing rates of tissue removal (Persson et al., 2005; De Jager and Pastor, 2008). We therefore model browsing effects on growth by allowing users to define a species-specific threshold fraction of available forage biomass, that if removed, triggers a reduction in ANPP in the subsequent year (GRT, Tables 1 and 2, Fig. 4), as well as defining a maximum proportional growth reduction at $100 \%$ forage biomass removal (GRM, Tables 1 and 2, Fig. 4). Although we explicitly model negative effects of browsing on growth, these equations do not rule-out the potential for positive effects of browsing on forage production. As we pointed out above (see Available Forage Biomass), any factor that reduces growth can serve to maintain cohorts within browse reach for a longer period of time, 
and ultimately increase forage biomass. In the case of browsing, whether a cohort remains within height reach depends on the local browsing rate and the tolerance of a given species to lost tissue.

Some studies have also reported increases in plant mortality rates in response to increasing browsing intensity (Krefting, 1974; Edenius et al., 1995; Heinen and Sharik, 1990; Augustine and Frelich, 1998; Horsley et al., 2003; Tilghman, 1989; Russell et al., 2001). We model browsing effects on cohort mortality similarly to effects on growth. Users define a species-specific threshold fraction of available forage biomass, that if removed, triggers an increase in the probability that a cohort will die in the subsequent year (MT, Tables 1 and 2, Fig. 4), as well as defining a maximum increase in mortality probability at $100 \%$ forage biomass removal (MM, Tables 1 and 2, Fig. 4).

\subsection{Test cases}

We tested the browse extension in two landscapes. One was a north-temperate forest in the eastern United States (Allegheny National Forest, ANF) with persistently high populations of white-tailed deer and the other was a boreal forest at Isle Royale National Park (ISRO), USA, where moose interact dynamically with the forested landscape and other factors that limit moose population density (Fig. 1). We therefore used the ANF simulation to illustrate the use of an externally defined population (BDI option) and the ISRO simulation to illustrate the use of an internally defined population (DBP option) that responds dynamically to spatial and temporal changes in food resources.

To derive parameter estimates and better understand the temporal dynamics of available forage biomass for these two simplified case studies, we integrated the browse extension calculations into the LANDIS-II-Site utility (L2-Site; Miranda and Sturtevant 2016, (L2-Site-Browse; https://sites.google.com/site/landismodel/projects/veg-site-tool). L2-Site-Browse is a Microsoft Windowsbased utility that implements the cohort and biomass growth and senescence equations of the Biomass Succession extension (v3.2) for up to six species on a single site, and includes all browse functions described above. We specifically examined the effects of different parameter estimates and combinations 
on the amount of available forage biomass within reach and the time it took cohorts to escape browse height. These simulations were conducted for single cohorts growing alone on a site and multiple cohort growing together and competing for growing space. Simulation results were compared with sapling height growth data and available forage biomass estimates from Persson et al. (2005), De Jager and Pastor (2008) and De Jager et al. (2009). The parameters in Table 1 yielded reasonable estimates of available forage biomass as well as the time that cohorts remained within browse height and supplied available forage biomass. Both competition and effects of browsing served to reduce cohort growth and available forage biomass, and prolonged the period of time that cohorts remained within height reach, which is consistent with the design of the parameters introduced in section 2.2.1 Available Forage Biomass.

\subsubsection{Allegheny National Forest}

The Allegheny National Forest (ANF) comprises an area of 2,092 $\mathrm{km}^{2}$ and lies within the Appalachian Plateau Geomorphic Province (Fig. 1). Northern hardwood species (e.g., Acer saccharum, A. rubra, Betula alleghaniensis, B. lenta, Fagus grandifolia, Prunus serotina, Quercus spp., and Tsuga canadensis) are most prevalent; current forest composition is strongly influenced by historic land use and management practices (Williams et al., 2005). We used USDA Forest Service Forest Inventory Analysis (FIA) data, along with ANF ecological land type data (Williams et al., 2005), and the US National Land Cover Database (Homer et al., 2015) in Landscape Builder ver 2.1.5 (Dijak, 2013) to develop LANDIS-II ecoregion and initial community maps (Appendix A) at 30m cell resolution. For the purposes of demonstrating the Browse extension, we chose to model the far Southeastern portion of ANF and we did not incorporate effects of fire or wind. Forest management regimes on the ANF at present represent very light harvesting (ranging down from $0.5 \%$ per year depending on management objectives), so we did not model harvesting impacts.

The Biomass Succession extension was parameterized using prior published plant species life history attributes and establishment and potential growth rates from Duveneck et al. (2014) (Appendix A). We conducted three replicate 100-year simulations for two scenarios: one with the browse extension turned on 
(with deer browsing) and another with the extension turned off (without browsing). After noting that the results of replicate simulations were nearly identical, we chose to report results for a single replicate. For the browsing scenario, we simulated a static deer population with an index (BDI) of 0.45 , which represents a moderate index value similar to conditions during the late $20^{\text {th }}$ century, as described by Tilghman (1989) and Horsley et al (2003). Plant species preferences and tolerances were derived from previously published studies (Table 2a). All species in the simulation could be browsed by deer (preference $>0$ ), with the most highly preferred species being A. rubrum, Quercus spp., and Q. rubra. Moderately preferred species consisted of T. canadensis, A. saccharum, B. alleghaniensis, B. lenta, while less preferred species included F. Grandifolia and P. serotina (see Table 2A for parameter estimates and supporting citations). The species most tolerant to browsing was $F$. grandifolia, followed by B. lenta and

B. allegheniensis. T. canadensis was the least tolerant species. We used a moving window in calculations of habitat suitability that varied between a $321 \mathrm{~m}$ radius for forage quantity and $1284 \mathrm{~m}$ radius for site preference (per Marquis, 1987). The larger radius for site preference was based on deer home range sizes for the region (Brenneman, 1987; Marquis, 1987; Rosenberry et al., 2009; Tierson et al., 1985). The smaller forage quantity radius was calculated as $1 / 4$ of the site preference value, or the area deer more locally occupy over the course of a year (Campbell et al., 2004; Rosenberry et al., 2009; Tierson et al., 1985; Webb et al., 2010) and the assumption that local foraging decisions are primarily based on forage availability.

\subsubsection{Isle Royale National Park, USA}

Isle Royale National Park (ISRO) is a $534 \mathrm{~km}^{2}$ island in the northwestern part of Lake Superioroff the coast of Minnesota and Ontario, Canada (Fig. 1). The vegetation types present on Isle Royale reflect its position within the temperate-boreal forest transition zone (Goldblum and Rigg, 2010), with species characteristic of the southern boreal forest (e.g., Abies balsamea, A saccharum, B. alleghaniensis, B. papyrifera, Picea glauca, Populus tremuloides, and Thuja occidentalis). The initial community map was 
developed by matching FIA data to similar forest types in a land cover dataset (TNC, 1999). Ecoregions were developed based on soils data (see Appendix A for more information). Cell resolution for this case study was set at 50 X $50 \mathrm{~m}$. We parameterized the Base Wind extension (v. 2.0) (Scheller and Mladenoff, 2005, Scheller and Domingo, 2013) using historical assessments of disturbance in Minnesota (White and Host, 2008) and assumed a constant wind regime for all simulations. We did not simulate effects of fire because there have been no large-scale fires on the island since the 1930s and the fire regime has been characterized as minor and episodic over a 4500 year period prior to settlement (Flakne and Cole, 1995).

We parameterized the Biomass Succession extension using plant species life history attributes and establishment and potential growth rates from a previously published study from similar forests in northeastern Minnesota (Appendix A, Duveneck et al., 2014). We then conducted three replicate 110-year simulations for two scenarios: one with the browse extension turned on (with moose browsing) and another with the extension turned off (without browsing). For the browsing scenario, population parameters were derived from a long-term study of wolf and moose population dynamics (Peterson et al. 2014). We simulated a moose population with an initial population of 1 moose per $\mathrm{km}^{2}$, similar to the long-term average. The population growth rate ranged between 0.15 and 0.25 , estimates made during an exponential increase in the moose population during the mid-1990s. Random mortality rates ranged between 0 and 0.1 , and wolf predation rates ranged between 0.03 and 0.1 , reflecting long-term average rates at Isle Royale (Peterson et al. 2014). The consumption rate was set at $2327 \mathrm{~kg}$ per moose per year, reflecting a daily intake rate of $10 \mathrm{~kg}$ dry mass in summer and $5 \mathrm{~kg}$ dry mass in winter (Persson et al. 2000), assuming that half of the year is winter and half is summer, and that $85 \%$ of dry matter intake is from woody plants (Persson et al., 2005). We used a single moving window size that approximated a moose home range (1500 m radius, Cederlund and Sand, 1994) in calculations of habitat suitability.

Plant species preferences and tolerances to browsing were derived from previously published studies (Table 2b). Preference values were derived from estimates of the fraction of available forage biomass that moose typically remove from different species in long-term studies conducted at Isle Royale 
(see parameter estimates and supporting citations in Table 2b). Species tolerances to browsing were primarily derived from De Jager et al. (2009) and De Jager and Pastor (2008). These studies have shown that the growth of conifers, such as A. balsamea, is typically more strongly influenced by browsing than boreal hardwood species such as B. papyrifera and $P$. tremuloides. Much less is known about how mortality is impacted by browsing. We therefore used a conservative approach to modelling mortality, with very high rates of tissue removal $(>80 \%)$ required to trigger mortality. Further, mortality thresholds were correlated with growth thresholds so that species less tolerant of browsing in terms of growth were also less tolerant of browsing in terms of survival.

\subsection{Data Analysis}

We examined results for the following model outputs for the two study areas: 1) moose population density (ISRO only), 2) average biomass removal (including that due to direct tissue removal by herbivory as well as indirect losses due to browsing induced cohort mortality), 3) average forage availability and the equivalent landscape carrying capacity (ISRO only), and 4) average aboveground live biomass (AGB, total and by species). The above averages represent total values across the entire simulation area, divided by the simulation area. Forest biomass estimates were attained from the LANDIS-II Biomass Output extension (v. 2; Scheller and Domingo, 2015). Finally, for both case studies we examined the sensitivity of: 1) total and species-specific biomass, 2) population density (ISRO only), 3) forage availability, 4) biomass removed from the landscape, and 5) number of cohorts killed by browsing. In both landscapes we increased and decreased the parameter estimates listed in table 1 by $10 \%$, and the percent difference in the response variables between the original and adjusted parameter estimates was calculated after 50 and 100 years across the entire landscapes to examine time-specific sensitivity to parameterization (see Sturtevant et al., 2012 more details on procedure). 


\section{Results}

\subsection{Allegheny National Forest}

In simulations with deer browsing, biomass removed from the ANF landscape fluctuated between 30 and $50 \mathrm{~g} / \mathrm{m}^{2}$ during the first two decades before gradually declining from 50 to $35 \mathrm{~g} / \mathrm{m}^{2}$ over the remainder of the simulations (Fig. 5). These early fluctuations may be artifacts of the initial conditions, but balance out relatively quickly to a moderately declining trend. During this same period of time, available forage biomass showed a shallow declining trend to near $23 \mathrm{~g} / \mathrm{m}^{2}$ in the simulations with deer browsing. In contrast, simulations without deer browsing resulted in a decrease in available forage biomass from year 30 to year 60 , before recovering to approximate the same level as simulations with deer browsing by the end of the simulations.

Deer browsing reduced total aboveground live biomass by $48 \%$ by the end of the simulations (Figs. 5 and 6). Browsing depressed total biomass of all species. However, the relative abundance of some species increased with deer browsing, particularly for species that were less preferred, had a higher tolerance for lost tissue, or both (Fig. 7). For example, the relative abundance of the moderately preferred and resilient B. alleghaniensis and B. lenta were 113 and $72 \%$ greater after 100 -year -simulations with deer browsing than they were after simulations without browsing. Other species increased more moderately to browsing, such as $F$. grandifolia $(+10 \%)$, which was moderately unpreferred and resilient to browsing and $P$. serotina (20\%), which was unpreferred but yet vulnerable to browsing. In contrast, Quercus spp. (-19\%), T. canadensis (-23\%), A. rubrum (-33\%), and A. saccharum (-54\%) all had lower relative abundance after 100-year-simulations with deer than in simulations without deer.

Sensitivity analysis to user-defined deer browsing parameters resulted in little effect on species composition or on forage biomass removed from the landscape and resulting cohorts killed. Total aboveground live biomass was not sensitive to minor (+/-10\%) changes in any of the browse extension parameters (Appendix B). Aboveground biomass of specific species was rarely sensitive to minor changes 
in model parameters. However, at year 50 and 100, F. grandifolia biomass tended to be most sensitive to parameter adjustments followed by $P$. serotina and A. saccharum. Of all of the parameter adjustments, a change in the Browse Biomass Threshold had the greatest effect on species biomass, affecting 5 of 9 species at year 50 by more than $10 \%$. At year 50, total biomass removed and cohorts killed decreased by 20.1 and $17.0 \%$ respectively in response to a $10 \%$ decrease in the deer population index. At year 100 , a $10 \%$ decrease in the deer population index resulted in species biomass increases for F. grandifolia, A. saccharum, and $P$. serotina. At year 100, P. serotina biomass decreased with a $10 \%$ increase in the deer population index.

\subsection{Isle Royale National Park}

The simulated moose population at Isle Royale initially increased from 1 to 2 moose per $\mathrm{km}^{2}$ during the first two decades of the simulations before equilibrating near 1.5 per $\mathrm{km}^{2}$ (Fig. 8). The biomass removed from the landscape showed a similar increasing trend during the first couple of decades of the model simulation before equilibrating near $15 \mathrm{~g} / \mathrm{m}^{2}$. Available forage biomass across the initial landscape was approximately $16 \mathrm{~g} / \mathrm{m}^{2}$, which is equivalent to a carrying capacity of approximately 7 moose per $\mathrm{km}^{2}$ in the model (Fig. 8 and 9). The rise in the moose population and biomass removal rates during the first few decades of the simulation corresponded with a reduction in available forage biomass to approximately 8 $\mathrm{g} / \mathrm{m}^{2}$ or a carrying capacity of approximately 3.5 moose per $\mathrm{km}^{2}$. Hence the long term population density was approximately $40 \%$ of the carrying capacity of the landscape, indicating that moose were directly removing $40 \%$ of the total forage availability. These removal rates reflect the effects of random mortality factors and wolf predation, which served to keep the moose population within $40 \%$ of carrying capacity. Such removal rates were sufficient to cause a reduction in available forage biomass, as the 'no moose' scenario sustained available forage biomass above $20 \mathrm{~g} / \mathrm{m}^{2}$ over the long-term (carrying capacity > 8 moose per $\left.\mathrm{km}^{2}\right)$. 
Moose browsing also reduced total aboveground live biomass by approximately $26 \%$ by the end of the simulations (Fig. 8). Effects of browsing were strongest and caused a decrease in the relative abundance of the most highly preferred species (A. balsamea (-500\%), B. papyrifera $(-154 \%)$, . tremuloides $(-190 \%)$, and the other deciduous species (-88\%)) (Fig. 10). Effects of browsing on the moderately preferred species were weaker (A. saccharum (-68\%), B. alleghaniensis (-22\%), and T. occidentalis (-26\%). Finally, unbrowsed species increased in biomass and relative abundance with browsing $(P$. glauca $(+60 \%), F$. nigra $(+80 \%)$, P. mariana $(+70 \%)$. Hence, browsing caused a shift in the composition of aboveground biomass away from the most highly preferred species and toward unbrowsed species (Fig. 10).

Total aboveground live biomass was not sensitive to minor (+/-10\%) changes in any of the browse input parameters at year 50 or year 100 (Appendix B). Further, the composition of aboveground biomass was rarely sensitive to minor changes in model parameters. Only 2 parameter changes resulted in a $20 \%$ change in forage availability (Initial population size and population growth rate). Population size appeared to be slightly sensitive to changes in parameters that influenced forage availability (and hence carrying capacity) as well as those that directly influenced population density (consumption rate and population growth rate). However, only one parameter change led to a $>25 \%$ change in population size $(-10 \%$ consumption rate) in year 50 , and by year 100 population size was back to within $2 \%$ of the original simulation (Appendix B).

The total biomass removed from the landscape and number of cohorts killed were much more sensitive to minor parameter changes than any of the other model outcomes. However, both increases and decreases in parameter estimates often had similar effects on these two outputs. In the first 50 years, all but 3 of the parameter changes led to increases in biomass removed and cohorts killed. Yet in year 100, all but 7 parameter changes led to decreases in biomass removed and cohorts killed. Further examination of other time steps not shown in Appendix B indicated that the sensitivity of these two parameters varied substantially over time, without any predictable trends. We believe that this is due to the fact that the total biomass removed from the landscape largely reflects a loss of biomass due to cohort mortality, which is a 
stochastic process. Hence, the sensitivity of these two model outcomes is more likely due to the stochasticity in model simulations than to changes in parameter inputs. Furthermore, despite relatively large changes in cohort mortality and biomass removed, total biomass remained relatively unchanged from the original estimates. A $>20 \%$ change in biomass removed or cohorts killed never corresponded with a change in total biomass that exceeded $12 \%$ (Appendix B).

\section{Discussion}

The LANDIS-II framework has enabled investigation of the effects of a wide-range of landscape-scale disturbances on northern forests (Gustafson et al., 2010; Scheller et al. 2011; Sturtevant et al., 2012; Duveneck et al., 2014). Effects of timber harvest, wind, fire, and insects are well represented by various extensions that plug into the core LANDIS-II model. In this paper, we outlined the development of a new browse extension similar to these previously developed extensions in scope and complexity. This new extension will allow researchers and managers to explore effects of browsing, as well as how browsing might interact with other disturbances known to impact forest productivity and succession. Although a number of spatially explicit models have been developed to examine plant-herbivore interactions (e.g., Moen et al., 1997, 1998; van Oene et al., 1999; Kramer et al., 2001, 2003; Coughenour, 2002; Forsyth et al., 2015; Riggs et al. 2015), few achieve the level of balance among plant and animal components or has such broad applicability for a variety of ungulates and forest systems. In the remainder of this paper we: 1) compare results from two case studies with previously published data to illustrate consistencies between model results and our current understanding of effects of browsing on forest ecosystems, 2) discuss the strengths and limitations of our modeling approach, and 3) introduce a series of additional questions that the model is well-suited to address. 


\subsection{Comparison and Validation of Case Studies}

Both case studies showed that browsing, represented as either an externally defined index (ANF simulation) or as an internally defined dynamic population (ISRO simulation) can reduce aboveground live biomass and change forest composition and succession. The primary difference between the two simulations was that available forage biomass was much more strongly impacted by herbivory at ISRO than at ANF, despite the fact that both populations were generally removing $40-45 \%$ of available forage biomass. We suggest that this difference has to do with complex relationships among biomass removal rates, foraging strategy, the number of species producing available forage biomass, and species-specific tolerances to lost tissue. At ANF, available forage biomass was supported by a larger species pool than the ISRO simulation, helping to explain why estimates of available forage biomass were generally lower at ISRO. Recall that our fractional foraging strategy removes a target fraction of available forage from species in rank order. If more biomass needs to be removed from a site, the most highly preferred species are browsed again. Thus, a smaller species pool will lead to higher browsing rates on highly preferred species where the population (or index) is large, relative to available forage biomass. We suggest that the greater diversity of species in the diet of deer at ANF simply dispersed browsing impacts to more species and reduced the overall impact of browsing. Indeed, foraging strategy has been shown to have large effects on available forage biomass and the sustainability of landscapes for ungulate populations in other plant-herbivore simulation models (Moen et al. 1998). In both simulations, available forage biomass was more dynamic in simulations without browsing as compared to simulations with browsing. We suggest that this is due to the relatively tight coupling between biomass removal (i.e., browsing) and forage biomass in the simulations with browsing. In contrast, available forage biomass in simulations without browsing were more likely to be influenced by other factors that might alter understory plant growth.

Nevertheless, both simulations resulted in strong declines in aboveground biomass and changes to forest succession, consistent with previously published field studies (see below). Not accounting for effects of browsing in forest ecosystems with dense ungulate populations may result in an over prediction of 
aboveground biomass and the abundance of species that are highly preferred and/or not tolerant of tissue removal. This is critical given that ungulates are abundant in a wide-array of forest ecosystems.

Although it is not possible to validate model outcomes for future scenarios, the trends in forest biomass and composition observed in both landscapes provide some confidence in model outputs. Across the northern Appalachians, moderate to high deer browsing delays, alters, and even prevents forest regeneration (Marquis 1981, Tilghman 1989, Horsley 2003, Royo 2016). In our simulations, browsing caused a strong reduction in total aboveground biomass despite the fact that the deer population was removing a small fraction of annual net primary productivity. However, because biomass removal is focused on young cohorts, browsing actively prevented recruitment into the tree stratum, thereby constraining the total biomass accrual in mature cohorts. Browsing impacts on tree regeneration were particularly acute on highly preferred species including A. rubrum, A. saccharum, T. canadensis, and Quercus spp. (Hough, 1965; Kain et al., 2011; Krueger et al., 2009; Long et al., 2007; Whitney, 1984). Modeled forest composition shifted towards less preferred B. lenta, and B. allegheniensis, P. serotina, and F. grandifolia with browsing; a result that is consistent with prior experimental work (Horsley et al., 2003). The relatively modest increase in beech is perhaps explained by its low abundance at the beginning of the simulation. Beech bark disease is not modeled in our simulations, and much of the observed increase in $F$. grandifolia regeneration in the region is a result of root-suckering from plants affected by the disease (Runkle 2007). The fact that $T$. canadensis increased in both simulations is unexpected, although the much greater increase without deer is consistent with the literature. T. canadensis is very shade tolerant, so some of these results are likely due to the fact that we did not include harvesting in our model, which would have favored less shade tolerant species. However, this particular species is impacted by such a wide-range of environmental factors that it has traditionally been difficult to model (Mladenoff and Sterns 1993).

At Isle Royale National Park, moose browsing limits recruitment of highly preferred plant species (Risenhoover and Maass, 1987; Brandner et al., 1990) and accelerates the rate of succession to unbrowsed species (Snyder and Janke, 1976, Mc Innes et al., 1992; Rotter and Rebertus, 2015). In particular, deciduous species, such as Populus tremuloides and B. papyrifera are browsed year-round, while Abies balsamea is 
heavily browsed in winter, especially in areas where it is rare and where moose densities are relatively high. Browsing of these species reduces their height growth and biomass where browsing rates are high (De Jager and Pastor, 2008; De Jager et al., 2009) and results in localized shifts toward unbrowsed Picea glauca (Snyder and Janke, 1976; Mc Innes et al., 1992; Rotter and Rebertus, 2015). Results from our simulations are consistent with predictions derived from these smaller-scale field studies as the most highly preferred hardwood species and Abies balsamea declined strongly in our simulations with browsing as compared to those without browsing. As a result, the composition of the landscape shifted toward unbrowsed and less browsed conifer species such as P. glauca, P. mariana, and T. occidentalis with moose browsing.

Finally, we were also able to validate our estimates of moose population density against long-term data collected at Isle Royale (Peterson et al. 2014). Using long-term average moose population and wolf predation parameters, our relatively simple population model was able to reproduce realistic estimates of moose population density on Isle Royale, and these population estimates are also similar to those in other boreal forests in Alaska and Sweden (Ball et al., 2000; Peterson et al., 2014; Paragi et al., 2015). Estimates of forage availability (and hence landscape carrying capacity) were also well within the range of previously published estimates for these same boreal forests in our browsing scenarios (Persson et al., 2005; De Jager et al., 2009; Lord and Kielland, 2015). In contrast, our simulations without browsing yielded extremely high and unrealistic estimates of carrying capacity $\left(\sim 8\right.$ per $\left.\mathrm{km}^{2}\right)$. Our population model relies on the ability to derive estimates of available forage biomass from annual net primary productivity via a series of userdefined parameter estimates. We calibrated these parameters at the site scale using data from previous field studies (Persson et al. 2005, De Jager and Pastor, 2009, De Jager et al., 2009). However, we suggest that future users examine site-scale behavior using the LANDIS-II-Site utility (L2-Site; Miranda and Sturtevant 2016), given that different species, ecoregions, and systems should vary in their ability to produce available browse. 


\subsection{Strengths and limitations of our approach}

\subsubsection{Effect of browsing on ecosystem structure and function}

Our primary objective was to better understand and represent browsing impacts on forest ecosystems, and we focused our attention on the growth and survival of woody species. However, persistently high rates of browsing by white-tailed deer on woody species and avoidance of herbaceous and some shrub species has been shown to create the formation of dense recalcitrant understory layers (e.g., hay-scented fern; Royo et al. 2006) that can alter, retard, or even arrest tree successional trajectories (Stromayer et al., 1997; Horsley et al., 2003; De Jager et al. 2013; Thrippleton et al. 2016). Similar impacts have been observed at Isle Royale National Park, where heavy moose browsing on deciduous species and avoidance of spruce can lead to the lack of tree recruitment and development of 'moose-spruce-savannahs' (Rotter and Rebertus, 2015). LANDIS-II, like most other forest dynamics models, is not specifically designed to investigate competitive interactions between trees and other growth forms. However, incorporation of the competitive effects of the herbaceous layer on forest recruitment may be important in browsing systems (Hill 1996; Thrippleton et al. 2016). Recent model developments made Riggs et al. (2015) to the FireBGC platform does enable investigation of competition between woody and herbaceous species, but this model does not allow for feedbacks to the ungulate population. Given that browsing has been shown to drive transition to non-woody species, future developments in LANDIS-II could help enable explicit investigation of this important phenomenon.

Browsing can also impact soil fertility when changes in the plant community correspond with a change in the quantity and quality of plant litter returned to the soil (Pastor et al. 1993). For example, moose can shift aboveground plant communities toward dominance by spruce, which has nutrient poor litter that decomposes slowly. Reductions to soil fertility could cause feedback to alter species establishment probabilities, growth rates, and competitive interactions. While the Biomass Succession extension that we employed here does track and model litter and wood decay, it does not extend these calculations to soil fertility. Future modelling efforts could extend browsing impacts to soil fertility by integrating the browse 
extension with the Century Succession extension (Scheller et al. 2011), which does simulate nutrient cycling.

Finally, the Browse Extension is currently designed to function with the Biomass Succession extension, which has a minimum time step of one year. Hence, important seasonal dynamics in plantherbivore interactions are not currently captured by our model. For example, herbivores often show strong seasonal differences in their total demand for forage biomass (Persson et al. 2005), their preferences for different plant species (Hodgson 2010), and their use of different portions of landscapes (Senft et al. 1987). Furthermore, different plant species often respond differently to tissue removal in summer as opposed to winter (Danell et al. 1994). In our applications, we attempted to summarize the net effects of within-year variability in consumption rates, foraging preferences and plant responses at an annual time step. For example, we adjusted the foraging preference parameter for balsam fir, a species moose only eat in winter, by assuming that half of the year is summer (preference $=0$ ) and half is winter (preference $=0.3$, Hodson 2010) resulting in a net annual preference value of 0.15 . This assumption further impacted the annual distribution of the animal population through the habitat suitability index. Thus seasonal differences in animal distribution and foraging pressure were only indirectly accounted for. We similarly attempted to summarize seasonal differences in the tolerance of each species to lost tissue and the per animal consumption rate at the annual time step. While it might be possible to similarly summarize other parameters in this way, users should consider whether summarizing the net effects of seasonal differences might mask processes important to their questions of interest. 


\subsubsection{Modeling species preferences and tolerances}

Perhaps the most important determinant of long-term effects of browsing on forest succession is the relationship between the preference of an herbivore for different plant species and the tolerance of those same plant species to biomass removal. Our goal was to capture the full range of possible preferencetolerance combinations by allowing users to define these parameters. Data are available to develop parameter estimates for plant species preferences. For example, in our ANF case study, we incorporated information from Latham et al. (2005), Marquis (1987), Tilghman (1989), Horsley et al. (2003) and Stout et al. (2013) to relate species preferences to categorical definitions of browse preference derived from various wildlife management plans or field studies. However, we acknowledge that detailed information for all plant species may not be available for all study areas. Nevertheless, it may be possible to derive such information from an understanding of plant chemistry. There are well-documented relationships between plant food selection and concentrations of lignin, nitrogen, sugar and toxic compounds for many plant species (Bryant and Kuropat 1980). Similarly, growth responses to lost tissue often differ between species that display determinate growth (e.g. conifers) and species that have indeterminate growth (e.g. deciduous species) (Millard et al., 2001). Depending on how much plant tissue is removed, it may take a year or more for browsed conifers to replace lost tissue (Edenius et al., 1995), whereas deciduous species may be able to replace lost tissue within the same season (Danell et al., 1985). These different growth forms may underpin the tolerance (or lack thereof) of different species to lost tissue. They also suggest that it may be possible to derive parameter estimates for preference and tolerance based on plant chemistry and growth form, helping to understand landscape-scale impacts of browsing that may emerge from much finer scale physiological processes. 


\subsubsection{Modeling Population Dynamics and Carrying Capacity}

There is a long history of empirical and theoretical research on animal population dynamics (Moran, 1950; Cappuccino and Price; 1995). Of the many population models that have been developed, we chose to use one of the simplest and most well-understood formulations, therefore allowing for a better understanding of the internal feedbacks between the animal and plant components of the full model. The discrete-time quadratic model has well-known dynamics, including chaotic behavior, that are dependent on the population growth rate (May, 1975). By changing the population growth rate, users have the ability to induce different (known) dynamics in the ungulate population without any change in the carrying capacity of the landscape or other sources of animal mortality. However, annual growth rates for ungulate populations should always fall between 0 and 1 . In our model, such growth rates produce a population that will smoothly approach carrying capacity and remain there over time (i.e., a stable point equilibrium). This is an important aspect of our model because it ensures that temporal changes in the population arise from stochastic variation in population parameters and/or changes in carrying capacity. Carrying capacity emerges from all factors that limit forage biomass production (including browse removal). In our application at Isle Royale, decadal fluctuations in the moose population reflected feedbacks between the carrying capacity of the landscape and the moose population. These feedbacks occurred even in the presence of wolf predation and some additional background mortality that served to maintain a population at approximately $40 \%$ of carrying capacity. Without such additional sources of mortality, the population could be expected to cycle with available forage biomass more frequently. But this assumption should be tested with additional case studies. Nevertheless, the model provides users with the ability to understand how large-scale changes in forest biomass and composition (including those induced by browsing) impact the capacity of landscapes to support herbivore populations. Those interested in additional feedbacks and interactions among the ungulate population and other sources of mortality and predation could further develop the population model in future iterations of the browse extension. 
We defined carrying capacity as the number of animals that could be supported by the forage biomass (quantity) available across the landscape and given a constant per animal consumption rate. However, some ungulates have the ability to lower their dietary intake and achieve a smaller body mass, which could lead to a larger population of smaller bodied animals (Lesage et al. 2001). The phenomenon could be incorporated into future iterations of the Browse Extension by making the consumption rate a more dynamic parameter. Or, perhaps it would be more appropriate to model herbivore biomass as opposed to animal density. Another limitation of our approach is that all forage types may not provide adequate energy or protein content. Hobbs and Swift (1985) developed a method that identifies the maximum amount of biomass obtainable from a mix of forage types, such that total biomass meets a minimum digestible energy or protein concentration. Incorporating nutritional content of plant foods into the definition of carrying capacity would require additional information on the chemistry of the plant foods in the diet of the herbivore, as well as additional parameterization. However, given that plant food selection and tolerance to browsing (see discussion above) as well as the energy and protein content of different species are all based on plant physiology and chemistry, it might be possible to develop more detailed approaches to modeling each of these processes as direct functions of plant physiology and chemistry. Finally, our model focuses on browsing ungulates that primarily feed on the live biomass associated with woody plants. However, browsing ungulates are known to feed on herbaceous vegetation during the summer growing season and even dead leaf litter can contribute to the forage base for some species (Ditchkof and Servello. 1998, Tremblay et al. 2005). There is not currently an extension for LANDIS-II that simulates the growth of herbaceous vegetation and so this component of the diet of ungulates is not accounted for by our model. The Biomass Succession extension that we utilized does track litter production, however litter is not currently transferred to the available forage biomass pool. Further development of the Browse Extension could be made to account for these contributions to ungulate carrying capacity. In the meantime, we suggest that users take into account some estimate of the non-woody biomass in the diet of the herbivore they are modelling and incorporate it into the estimate of annual consumption rate. For example, we estimated that $85 \%$ of the annual dry matter intake for moose is from woody plants (Persson et al., 2005) and we used this 
estimate to reduce the annual per animal forage demand. This approach may work well for a species such as moose, but may not be appropriate for other species that consume a much larger fraction of biomass from herbaceous species (e.g., elk).

\subsubsection{Habitat Suitability}

In both the dynamic and non-dynamic applications of our model, we employ moving window algorithms to scale-up site specific information about the abundance and composition of different forage resources as a way to link the herbivore population to impacts on individual sites. However, herbivore population distributions may reflect broad-scale distributions of other environmental variables, such as topography and avoidance of or preference for specific land cover types (Senft et al. 1987). Although we did not incorporate such information in our model application, the architecture of the model should easily support the incorporation of other internal (model-derived) or external geographic data sets in determining the factors affecting the spatio-temporal distribution of the browser population and associated browsing rates. In addition, spatially explicit data sets on herbivore population density exist for some systems and could be used to calibrate and validate population distributions produced by our model.

\subsection{Future Research and Management Applications}

Browsing ungulates inhabit a wide-range of forest ecosystems and they can cause changes to forest productivity, aboveground biomass, and successional trajectories through selective foraging on species that often dominate early succession. However, the long-term and large-scale effects of ungulates on forest succession are not well understood given the difficulties inherent in projecting species interactions and scaling up small-scale effects on plant growth and forage production. We have developed a process-based spatially explicit model that should help to provide a more rigorous method of scaling the effects of ungulate browsing to landscape scales and long time periods ( $>100$ years) and thus provide a better understanding of browsing on forest succession. Browsing can also interact with other disturbance regimes (e.g. wind, 
fire, harvesting, and insects) to further alter forest productivity and composition in ways that may feedback to change future disturbance regimes and browsing impacts. Our model can be used to address a range of potential research and management questions revolving around the interactive effects of browsing, disturbances, and vegetation dynamics at landscape scales. For example, how does browsing interact with timber harvesting? How does browsing interact with other disturbance regimes, including fire, wind and insect outbreaks? How does browsing interact with climate change effects on species establishment and growth rates and how does climate affect the herbivore population and its impacts on forest growth? How do different herbivore population management actions such as hunting and predator population management interact with forest productivity to modify herbivore population size, landscape carrying capacity, and forest structure? These questions have fundamental implications for many forested ecosystems worldwide supporting populations of browsing ungulates.

\section{Acknowledgments:}

This research was funded by the Natural Resources Preservation Program, a collaborative U.S. Geological Survey (USGS) and National Park Service (NPS) program through which USGS scientists address priority research needs identified by the NPS. This research was also supported by the USDA Forest Service Northern Research Station, Irvine, PA, and the U.S. National Fire Plan. We thank Mr. Paul Roth for early contributions towards this research. Jason Rohweder and Timothy Fox (USGS) helped to create initial communities and ecoregion files for the Isle Royale simulations. Comments from David Mladenoff, John Pastor, and two anonymous reviewers have greatly improved this manuscript. Any use of trade, product, or firm names is for descriptive purposes only and does not imply endorsement by the U.S. Government. 


\section{5. $\quad$ Literature Cited}

Alverson, W.S., Waller, D.M., Solheim, S.L., 1988. Forests too deer: edge effects in northern Wisconsin. Conserv. Biol. 2, 348-458.

Anderson, R.C., Loucks, O.L., 1979. White-tail deer (Odocoileus virginianus) influence on structure and composition of Tsuga canadensis forests. Journal of Applied Ecology 855-861.

Angelstam, P., Wikberg, P.E., Danilov, P., Faber, W.E., Nygrén, K., 2000. Effects of moose density on timber quality and biodiversity restoration in Sweden, Finland, and Russian Karelia. Alces 36, 133-145.

Augustine, D. J., Frelich, L. E., 1998. Effects of White-Tailed Deer on populations of an understory forb in fragmented deciduous forests. Conservation Biology 12, 995-1004.

Ball, J.P., Danell, K., Sunesson, P., 2000. Response of a herbivore community to increased food quality and quantity: an experiment with nitrogen fertilizer in a boreal forest. Journal of Applied Ecology 37247 255.

Bee, J. N., A. J. Tanentzap, W. G. Lee, R. B. Lavers, A. F. Mark, J. A. Mills, D. A. Coomes. 2009. The benefits of being in a bad neighbourhood: plant community composition influences red deer foraging decisions. Oikos 118:18-24.

Begon, M., Harper, J.L., Townsend, C.R., 1996. Ecology. Individuals, populations and communities. Blackwell Scientific Publications; Boston, Oxford, London, Edinburgh and Melbourne 945 pp.

Brandner, T.A., Peterson, R.O., Risenhoover, K.L., 1990. Balsam fir on Isle Royale: effects of moose herbivory and population density. Ecology 59, 155-164.

Bryant, J.P., Kuropat, P.J., 1980. Selection of winter forage by subarctic browsing vertebrates: The role of plant chemistry. Ann. Rev. Ecol. Syst. 11, 261-285.

Butler, L.G., Kielland, K., 2008. Acceleration of vegetation turnover and element cycling by mammalian herbivory in riparian ecosystems. Journal of Ecology 96, 136-144.

Carson, W. P., A. A. Royo, and C. J. Peterson. 2014. A pox on our land: a case study of chronic deer overbrowsing throughout the Allegheny National Forest region of Pennsylvania. Pages 400 - 411 in F. S. Gilliam, editor. The herbaceous layer in forests of eastern North America. Oxford University Press, New York, NY.

Cedarlund, G., Sand, H., 1994. Home-range site in relation to age and sex in moose. J. of Mammalogy. 75, 1005-1012.

Cappuccino, N., Price, P.W., 1995. Population Dynamics: New Approaches and Synthesis. Academic Press.

Cedarlund, G., Sand, H., 1994. Home-range site in relation to age and sex in moose. J. of Mammalogy. 75, 1005-1012. 
Coughenour, M.B., 2002. Elk in the Rocky Mountain National Park Ecosystem - a model-based assessment. Final Report USGS. NPS.

Côté, S. D., J. Beguin, S. de Bellefeuille, E. Champagne, N. Thiffault, J. P. Tremblay. 2014. Structuring Effects of Deer in Boreal Forest Ecosystems. Advances in Ecology 2014: Article ID 917834

Danell, K., Huss-Danell, K., Bergström, R., 1985: Interactions between browsing moose and two species of birch in Sweden. Oikos 44, 75-81.

Danell, K., Bergström, R., Edenius, L., 1994. Effects of large mammalian browsers on architecture, biomass, and nutrients of woody plants. Journal of Mammalogy 75, 833-844.

Danell, K., Bergström, R., Duncan, P., Pastor, J., 2006. Large herbivore ecology, ecosystem dynamics, and conservation. Cambridge University Press: Conservation Biology 11. 506 pp.

deCalesta, D. S.,1994. Effect of white-tailed deer on songbirds within managed forests in Pennsylvania. The Journal of Wildlife Management 58,711-718.

deCalesta, D. S., Stout, S. L., 1997. Relative deer density and sustainability: a conceptual framework for integrating deer management with ecosystem management. Wildlife Society (USA), 25, 252-258.

deGraaf, R. M., Healy, W. M.,Brooks, R. T., 1991. Effects of thinning and deer browsing on breeding birds in New England oak woodlands. Forest Ecology and Management 41, 179-191.

De Jager, N.R., Pastor, J., 2008. Effect of moose Alces alces population density and site productivity on the canopy geometries of birch Betula pubescens and B. pendula and Scots pine Pinus sylvestris. Wildlife Biology 14, 251-262.

De Jager, N.R., Pastor, J., 2009. Declines in moose population density at Isle Royale National Park, MI, USA and accompanied changes in landscape patterns. Landscape Ecology 24, 1389-1403.

De Jager, N.R., Pastor, J., Hodgson, A.L., 2009. Scaling the effects of moose browsing on forage distribution, from the geometry of plant canopies to landscapes. Ecological Monographs 79, 281-297.

De Jager, N.R., Cogger, B.J., Thomsen, M.T., 2013. Interactive effects of flooding and deer browsing on floodplain forest recruitment. Forest Ecology and Management 303, 11-19.

Dijak, W., 2013. Landscape Builder: software for the creation of initial landscapes for LANDIS from FIA data. Computational Ecology and Software, 3, 17-25.

Duveneck, M.J., Scheller, R.M., White, M.A., Handler, S.D., Ravenscroft, C., 2014. Climate change effects on northern Great Lake (USA) forests: A case for preserving diversity. Ecosphere 5(2) article 23.

Edenius, L., Danell, K., Nyquist, H., 1995. Effects of simulated moose browsing on growth, mortality, and fecundity in Scots pine: relations to plant productivity. - Canadian Journal of Forest Research 25, 529-535.

Eschtruth, A. K., J. J. Battles. 2008. Deer herbivory alters forest response to canopy decline caused by an exotic insect pest. Ecological Applications 18:360-376. 
Flakne, R.L., Cole, K.L., 1995. The Holocene landscape history of Isle Royale. Bulletin of the Ecological Society of America 76, 81 p.

Forsyth, D. M., D. J. Wilson, T. A. Easdale, G. Kunstler, C. D. Canham, W. A. Ruscoe, E. F. Wright, L. Murphy, A. M. Gormley, and A. Gaxiola. 2015. Century-scale effects of invasive deer and rodents on the dynamics of forests growing on soils of contrasting fertility. Ecological Monographs 85:157-180.

Foster, D., Swanson, F., Aber, J., Burke, I., Brokaw, N., Tilman, D., Knapp, A., 2003. The importance of land-use legacies to ecology and conservation. BioScience, 53, 77-88.

French, C.E., McEwen, L.C., Magruder, N.D., Ingram, R.H., Swift, R.W., 1956. Nutrient requirements for growth and antler development in the white-tailed deer. The Journal of Wildlife Management, 221-232.

Goldblum, D., Rigg, L.S., 2010. The deciduous forest-boreal forest ecotone. Geography Compass 4,701717.

Gustafson, E.J., A.Z. Shvidenko, B.R. Sturtevant, R.M. Scheller. 2010. Predicting global change effects on forest biomass and composition in south-central Siberia. Ecological Applications 20:700-715.

Healy, W. M., 1971. Forage preferences of tame deer in a northwest Pennsylvania clear-cutting. Journal of Wildlife Management 35,717-723.

Healy, W. M., 1997. Influence of deer on the structure and composition of oak forests in central Massachusetts. Pages 249-266 in W. J. McShea, H. B. Underwood, and J. H. Rappole, editors. The science of overabundance: deer ecology and population management. Smithsonian Institution Press, Washington, D.C., USA.

Heinen, J.T., Sharik, T.L., 1990. The influence of mammalian browsing on tree growth and mortality in the Pigeon River State Forest, Michigan. Am. Mid. Nat. 123, 202-206.

Hewitt, D. G., 2011. Nutrition. In: Hewitt, D. G. (Ed.). Biology and management of white-tailed deer. CRC Press. pp 75-106.

Hill, J. D. 1996. Population dynamics of hay-scented fern (Dennstaedtia punctilobula) and its effects on the composition, structure, and dynamics of a northeastern forest. Ph.D. University of Connecticut, Storrs, Connecticut.

Hobbs, N. T., 1996. Modification of ecosystems by ungulates. Journal of Wildlife Management 60, 695713.

Hobbs, N.T., Swift, D.M., 1985. Estimates of carrying capacity incorporating explicit nutritional constraints. Journal of Wildlife Management. 29, 814-822.

Hodgson, A.L., 2010. Temporal changes in spatial patterns of moose browse, causes and consequences. PhD Dissertation. University of Minnesota. $156 \mathrm{pp}$.

Homer, C.G., Dewitz, J.A., Yang, L., Jin, S., Danielson, P., Xian, G., Coulston, J., Herold, N.D., Wickham, J.D., Megown, K., 2015. Completion of the 2011 National Land Cover Database for the conterminous United States-Representing a decade of land cover change information. Photogrammetric Engineering and Remote Sensing 81, 345-354 
Horsley, S. B., Stout, S. L., DeCalesta, D. S., 2003. White-tailed deer impact on the vegetation dynamics of a northern hardwood forest. Ecological Applications 13, 98-118.

Hough, A.F., 1965. A twenty-year record of understory vegetational change in a virgin Pennsylvania forest. Ecology 46, 370-373.

Kain, M., Battaglia, L., Royo, A., Carson, W.P., 2011. Over-browsing in Pennsylvania creates a depauperate forest dominated by an understory tree: results from a 60 -year-old deer exclosure. The Journal of the Torrey Botanical Society 138, 322-326.

Kramer, K., Baveco, H., Bijlsma, R.J., 2001. Landscape forming processes and diversity of forested landscapes. Description and application of the model FORESPACE. Wageningen: Alterra, Green World Research.

Kramer, K., Groen, T.A., van Wieren, S.E., 2003. The interacting effects of ungulates and fire on forest dynamics: an analysis using the model FORESPACE. Forest Ecology and Management. 181, 205-222.

Krefting, L.W., 1974. The Ecology of the Isle Royale Moose with Special Reference to the Habitat. Agricultural Experiment Station Technical Bulletin No. 297, University of Minnesota, Minneapolis, Minn.

Krueger, L. M., C. J. Peterson, A. Royo, W. P. Carson. 2009. Evaluating relationships among tree growth rate, shade tolerance, and browse tolerance following disturbance in an eastern deciduous forest. Canadian Journal of Forest Research 39:2460-2469.

Lesage, L., Crête, M., Huot, J., Ouellet, J.-P., 2001. Evidence for a trade-off between growth and body reserves in northern white-tailed deer. Oecologia 126, 30-41

Latham, R. E., Beyea, J., Benner, M., Dunn, C.A.,Fajvan, M.A., Freed, R.R.,Grund, M.,Horsley, S.B., Rhoads, A.F.,Shissler, B.P., 2005. Managing White-tailed Deer in Forest Habitat from an Ecosystem Perspective: Pennsylvania Case Study. Report by the Deer Management Forum for Audubon Pennsylvania and Pennsylvania Habitat Alliance, Harrisburg. xix +340 pp.

Long, Z.T., Pendergast, T.H., Carson, W.P., 2007. The impact of deer on relationships between tree growth and mortality in an old-growth beech-maple forest. Forest Ecology and Management 252, 230-238.

Lord, R., Kielland, K., 2015. Effects of variable fire severity on forage production and foraging behavior of moose in winter. Alces 51, pages

Marquis, D. A., 1981. Effect of deer browsing on timber production in Allegheny hardwood forests of northwestern Pennsylvania. USDA Forest Service Research Paper NE-475. Northeastern Forest Experiment Station, Broomall, Pennsylvania, USA.

Marquis, D. A., 1987. Silvicultural techniques for circumventing deer browsing. In: Cochran, Roe S., chair. Proc. Symp.; Deer, Forestry and Agriculture: Interactions and strategies for management. 1987 June 15-17. Warren, PA. Erie, PA: Plateau \& North. Hardwood Chap., Allegheny Soc. Amer. For. p. 125-136. 183p.

May, R.M., 1975. Biological populations obeying difference equations: stable points, stable cycles, and chaos. J. Theor. Biol. 51, 511-524. 
McInnes, P., Naiman, R.J., Pastor, J., Cohen, Y., 1992. Effects of moose browsing on vegetation and litter of the boreal forest, Isle Royale, Michigan, USA. Ecology 73, 2059-2975.

McLaren, B.E., Peterson, R.O., 1994. Wolves, moose, and tree rings on Isle Royale. Science 266, 15551558.

Millard, P., Hester, A., Wendler, R., 2001. Interspecific defoliation responses on sites of winter nitrogen storage. Functional Ecology 15, 535-543.

Miranda, B.R., Sturtevant, B.R., 2016. LANDIS-II-Site v2.4 User Guide. Published online by the LANDIS-II Foundation (URL: http://www.landis-ii.org/users), accessed March 2016.

Mladenoff, DJ, GE Host, J Boeder, TR Crow. (1993) 1996. LANDIS: a spatial model of forest landscape disturbance, succession, and management. Pages 175-179 in M.F. Goodchild, L.T. Steyaert, B. O. Parks, C. Johnston, D. Maidment, M. Crane, S. Glendining, eds. GIS and environmental modeling. GIS World Books, Fort Collins, CO, USA.

Mladenoff, DJ, Sterns, F. 1993. Eastern Hemlock regeneration and deer browsing in the Northern Great Lakes Region: A re-examination and model simulation. Conservation Biology 7: 889-900.

Mladenoff, DJ, HS He. 1999. Design, behavior and applications of LANDIS, an object-oriented model of forest landscape disturbance and succession. Chapter 6 in Mladenoff, DJ and WL Baker, editors. Spatial modeling of forest landscape change: Approaches and applications. Cambridge University Press, Cambridge, UK.

Moen, R., Pastor, J., Cohen, Y., 1997. A spatially explicit model of moose foraging and energetics. Ecology $78,505-521$.

Moen, R., Pastor, J., Cohen, Y., 1998. Evaluating foraging strategies with a moose energetics model. Ecosystems 1, 52:63.

Moran, P.A.P., 1950. Some remarks on animal population dynamics. Biometrics 6, 250-258.

Murie, A., 1934. The moose of Isle Royale. University of Michigan Museum of Zoology Miscellaneous Publication number 25. University of Michigan Press.

Mysterud, A., 2006. The concept of overgrazing and its role in management of large herbivores. Wildlife Biology 12, 129-141.

Niklas, K.J., Enquist, B.J., 2002. Canonical rules for plant organ biomass partitioning and annual allocation. American Journal of Botany 89, 812-819.

Nuttle, T., Yerger, E. H., Stoleson, S. H., Ristau, T. E., 2011. Legacy of top-down herbivore pressure ricochets back up multiple trophic levels in forest canopies over 30 years. Ecosphere, 1-11.

Nuttle, T., Royo, A.A., Adams, M.B., Carson, W.P., 2013. Historic disturbance regimes promote tree diversity only under low browsing regimes in eastern deciduous forest. Ecological Monographs 83, 3-17. 
Paragi, T.F., Seaton, T.C., Kellie, K.A., Boertje, D., Kielland, K., Young, D.D., Keech, M.A., DuBois, S.D., 2015. Browse removal, plant condition, and twinning rates before and after short-term changes in moose density. Alces 51,

Parikh, G.L., 2015. The influence of diet composition, plant defensive chemicals, and winter severity on the nutritional condition of a free ranging generalist herbivore. Master's Thesis, Michigan Technological University.

Pastor, J., Naiman, R.J., 1992. Selective foraging and ecosystem processes in boreal forests. Am. Nat. 139, 690-705.

Pastor, J.P., Cohen, Y., 1997. Herbivores, the functional diversity of plant species, and the cycling of nutrients in ecosystems. Theoretical Population Biology. 51, 165-179.

Pastor, J., Danell, K., 2003. Moose-vegetation-soil interactions: a dynamic system. Alces 39,177-192.

Persson, I-L., Danell, K., Bergström, R., 2000. Disturbance by large herbivores in boreal forests with special reference to moose. Ann. Zool. Fennici 37, 251-263.

Persson, I-L., Danell, K., Bergström, R., 2005. Different moose densities and accompanied changes in tree morphology and browse production. Ecological Applications 15, 1296-1305.

Peterson, R.O., Vucetich, J.A., Bump, J.M., Smith, D.W., 2014. Trophic cascades in a multicausal world: Isle Royale and Yellowstone. Annual Review of Ecology, Evolution, and Systematics 45, 325-345.

Riggs, R.A., Keane, R.E., Cimon, N., Cook, R., Holsinger, L., Cook, J., DelCurto, T., Bagett, L.S., Justice, D., Powell, D., Vavra, M., Naylor, B., 2015. Biomass and fire dynamics in a temperate forest-grassland mosaic: Integrating multi-species herbivory, climate, and fire with the FireBGCv2/GrazeBGC system. Ecological Modelling 296: 57-78.

Risenhoover, K.L., 1987. Winter foraging strategies of moose in subarctic and boreal forest habitats. Ph.D Dissertation. Michigan Technological University. 108 pp.

Risenhoover, K.L., Maass, S.A., 1987. The influence of moose on the composition and structure of Isle Royale forests. Can. J. For. Res. 17, 357-364.

Rooney, T.P., Waller, D.M., 2003. Direct and indirect effects of white-tailed deer in forest ecosystems. Forest Ecology and Management 181, 165-176.

Rooney, T. P., R. Buttenschøn, P. Madsen, C. R. Olesen, A. A. Royo, S. L. Stout. 2015. Integrating ungulate herbivory into forest landscape restoration. Restoration of Boreal and Temperate Forests 13:69.

Rotter, M.C., Rebertus, A.J., 2015. Plant community development of Isle Royale's moose-spruce savannas. Botany 93, 75-90.

Royo, A.A. Carson, W.P., 2006. On the formation of dense understory layers in forests worldwide: consequences and implications for forest dynamics, biodiversity, and succession. Canadian Journal of Forest Research 36, 1345-1362. 
Royo, A.A., Collins, R., Adams, M.B., Kirschbaum, C. Carson, W.P., 2010. Pervasive interactions between ungulate browsers and disturbance regimes promote temperate forest herbaceous diversity. Ecology 9193 105.

Royo, A.A., Stout, S.L., deCalesta, D.S., Pierson, T.G., 2010. Restoring forest herb communities through landscape-level deer herd reductions: Is recovery limited by legacy effects? Biological Conservation 143, 2425-2434.

Royo, A. A., D. W. Kramer, K. V. Miller, N. P. Nibbelink, S. L. Stout. 2016. The canary in the coal mine: Sprouts as a rapid indicator of browse impact in managed forests. Ecological Indicators 69:269-275

Runkle, J. R. 2007. Impacts of beech bark disease and deer browsing on the old-growth forest. The American Midland Naturalist 157:241-249.

Russell, F. L., Zippin, D. B., Fowler, N. L., 2001. Effects of white-tailed deer (Odocoileus virginianus) on plants, plant populations and communities: a review. The American Midland Naturalist, 146(1), 1-26.

Scheller, R. M., Mladenoff, D.M., 2004. A forest growth and biomass module for a landscape simulation model, LANDIS: design, validation, and application. Ecological Modelling 180, 211-229.

Scheller, R. M., D. J. Mladenoff., 2005. A spatially interactive simulation of climate change, harvesting, wind, and tree species migration and projected changes to forest composition and biomass in northern Wisconsin, USA. Global Change Biology 11, 307-321.

Scheller, R.M., Domingo, J.B., Sturtevant, B.R., Williams, J.S., Rudy, A., Gustafson, E.J., Mladenoff, D.J., 2007. Design, development and application of LANDIS-II, a spatial landscape simulation model with flexible temporal and spatial resolution. Ecological Modelling 201, 409-419.

Sheller, R.M., Hua, D., Bolstad, P.V., Birdsey, R., Mladenoff, D.J., 2011. The effects of forest harvest intensity in combination with wind disturbance on carbon dynamics in a Lake States mesic landscape. Ecological Modelling 222, 144-153.

Scheller, R.M., Domingo, J.B., 2013. LANDIS-II Base Wind v2.1 Extension User Guide. Published online by the LANDIS-II Foundation (URL: http://www.landis-ii.org/extensions/biomass-output), accessed February 2016.

Scheller and Miranda (2015). LANDIS-II Biomass Succession v3.2 Extension User Guide. Published online by the LANDIS-II Foundation (URL: http://www.landis-ii.org/extensions/biomass-succession), accessed February 2016.

Scheller, R.M., Domingo, J.B., 2015. LANDIS-II Biomass Output v2.1 Extension User Guide. Published online by the LANDIS-II Foundation (URL: http://www.landis-ii.org/extensions/biomass-output), accessed February 2016.

Sell, S.M., 2007. Interactions between moose and their primary forage at Isle Royale National Park, Lake Superior. PhD Dissertation. University of Minnesota. $121 \mathrm{pp}$. 
Senft, R.L., Coughenour, M.B., Bailey, D.W., Rittenhouse, L.R., Sala, O.E., Swift, D.M., 1987. Large herbivore foraging and ecological hierarchies. Bioscience 37, 789-799.

Shipley, L.A., Forbey, J.S., Moore, B.D., 2009. Revisiting the dietary niche: when is a mammalian herbivore a specialist? Integrative and Comparative Biology 49, 274-290.

Skarpe C, Hester AJ 2008) Plant traits, browsing and grazing herbivores, and vegetation dynamics. In: Gordon IJ, Prins HT (eds The ecology of browsing and grazing. Springer, Berlin, pp 217-261

Snyder, J.D., Janke, R.A., 1976. Impact of moose browsing on boreal-type forests of Isle Royale National Park. Am Midl Nat 95, 79-92.

Stout, S. L., Royo, A. A., deCalesta, D. S., McAleese, K., Finley, J.C., 2013. The Kinzua Quality Deer Cooperative: can adaptive management and local stakeholder engagement sustain reduced impact of ungulate browsers in forest systems?. Boreal Environment Research, 18(Suppl. A), 50-64.

Sturtevant, B.R., B.R. Miranda, D.J. Shinneman, E.J. Gustafson, P.T. Wolter. 2012. Comparing contemporary and presettlement forest dynamics in the Boundary Waters Canoe Area Wilderness (USA) Does spruce budworm disturbance enhance fire risk? Ecological Applications 22:1278-1296.

Stromayer, K.A.,Warren, R.J., 1997. Are overabundant deer herds in the eastern United States creating alternate stable states in forest plant communities? Wildlife Society Bulletin, pp.227-234.

The Nature Conservancy., 1999. USGS-NPS Vegetation Mapping Program: Classification of the Vegetation of Isle Royale National Park.

Tilghman, N. G., 1989. Impacts of white-tailed deer on forest regeneration in northwestern Pennsylvania. J. Wildl. Manage. 53,524-532.

Thrippleton, T., Bugmann, H., Kramer-Priewasser, K., Snell, R.S., 2016. Herbaceous understory: an overlooked player in forest landscape dynamics? Ecosystems 19: 1-15.

Tripler, C. E., C. D. Canham, R. S. Inouye, J. L. Schnurr. 2005. Competitive hierarchies of temperate tree species: Interactions between resource availability and white-tailed deer. Ecoscience 12:494-505.

USDA Forest Service. 2014. Allegheny National Forest Monitoring and Evaluation Report FY 2008- FY 2013. Warren, PA: USDA Forest Service. 294 pages.

van Oene, H., Van Deursen, E.J.M., Berendse, F., 1999. Plant-herbivore interaction and its consequences for succession in wetland ecosystems: a modeling approach. Ecosystems 2, 122-138.

Vila, B, Vourc'h, G., Gillon, D., Martin, J-L., Guibal, F., 2002. Is escaping deer browse just a matter of time in Picea sitchensis? A chemical and dendroecological approach. Trees 16, 488-496.

Weisberg, P.J., M.B. Coughenour, and H. Bugmann., 2006. Integration of large herbivore-vegetation processes in a landscape context. In Large herbivore ecology, ecosystem dynamics and conservation, edited by Kjell Danell, Roger Bergström, Patrick Duncan and John Pastor, 348-382. Cambridge: Cambridge University Press. 
White, M.A., Host, G.E., 2008. Forest disturbance frequency and patch structure from pre-European settlement to present in the Mixed Forest Province of Minnesota, USA. Canadian Journal of Forest Research $38,2212-2226$.

Whitney, G.G., 1996. From coastal wilderness to fruited plain: a history of environmental change in temperate North America from 1500 to the present. Cambridge University Press. 488 pp.

Whitney, G.G., 1984. Fifty years of change in the arboreal vegetation of Heart's Content, an old-growth hemlock-white-pine-northern hardwood stand. Ecology 65, 403-408.

Williams, C.E., Mosbacher, E.V.,Moriarity, W.J., 2000. Use of turtlehead (Chelone glabra L.) and other herbaceous plants to assess intensity of white-tailed deer browsing on Allegheny Plateau riparian forests, USA. Biological Conservation 92,207-215.

Zamora, R., Gómez, J.M., Hódar, J.A., Castro, J., García, D., 2001. Effects of browsing by ungulates on sapling growth of Scots pine in a Mediterranean environment: consequences for forest regeneration. Forest Ecology and Management 144, 33-42. 
Figure Captions

Figure 1. The LANDIS-II Browse Extension was applied to two landscapes to illustrate its functionality, Allegheny National Forest in Pennsylvania, USA, and at Isle Royale National Park, Michigan, USA.

Figure 2. The sequence of model calculations for the Browse Extension. At each time step a series of site and landscape attributes are calculated (inset) and used to distribute the browser population and associated browse impacts to sites. Forage biomass removal is based on user defined species browse preferences and consumption rates. Cohort damage is based on user defined species-specific tolerance to browsing impacts. At the end of each time step the degree to which cohort growth and mortality are impacted at the next time step are calculated and used to influence cohort growth and survival in the Biomass Succession extension. See methods for more details.

Figure 3. In the LANDIS-II Browse Extension, browsing impacts are downscaled to sites using a Habitat Suitability Index (HSI). Users have the option to calculate HSI using moving window averages of forage availability $\left(\mathrm{A}, \mathrm{g} / \mathrm{m}^{2}\right)$ or site preference (B, unitless). Shown here are HSI maps (C and D, unitless) for the western portion of Isle Royale, using a $40 \mathrm{~km}^{2}$ moving window. HSI in map $\mathrm{C}$ is derived from forage availability alone (A), and used to downscale the population (and browsing impacts) in map E (\#/km²). HSI in map D is derived from site preference alone (B) and used to downscale the population (and browsing impacts) in map $\mathrm{F}\left(\# / \mathrm{km}^{2}\right)$.

Figure 4. In the LANDIS-II Browse Extension, removal of plant tissue results in a direct reduction in aboveground live biomass during a given time step. Effects of browsing on cohort growth and survival during the next time step can also be incorporated by defining a threshold proportion of available forage biomass removed, which triggers a growth and/or survival response, and by defining the maximum growth or survival response when $100 \%$ of available forage biomass is removed. Shown here are the browse effect parameters used in modelling at Allegheny National Forest (see Table 2A) and Isle Royale National Park (see Table 2B).

Figure 5. Model results for the Allegheny National Forest with deer browsing (black lines) and without deer browsing (gray lines). Note that only results for black lines (deer browsing) are plotted for biomass removed because the no deer scenario did not include this model outcome.

Figure 6. Changes in the distribution of total aboveground live biomass at Allegheny National Forest over a 100-year period with and without simulated deer browsing. Browsing causes an overall reduction in total biomass across the landscape.

Figure 7. The composition of total above ground live biomass for model simulations with and without browsing by deer at Allegheny National Forest. Note that browsing causes a shift in composition away from the most highly preferred species and toward less preferred species (species preferences are given in Table 2A).

Figure 8. Model results for the Isle Royale landscape with moose browsing (black lines) and without moose browsing (gray lines). Note that only black lines are plotted for population density and biomass removed because the no moose scenario did not include these model outcomes. 
Figure 9. Changes to the distribution of available forage biomass at Isle Royale National Park with and without simulated moose browsing.

Figure 10. The composition of total above ground live biomass for model simulations with and without browsing by moose at Isle Royale National Park. Note that browsing causes a shift in composition away from the most highly preferred species and toward less preferred species (species preferences are given in Table 2b). 


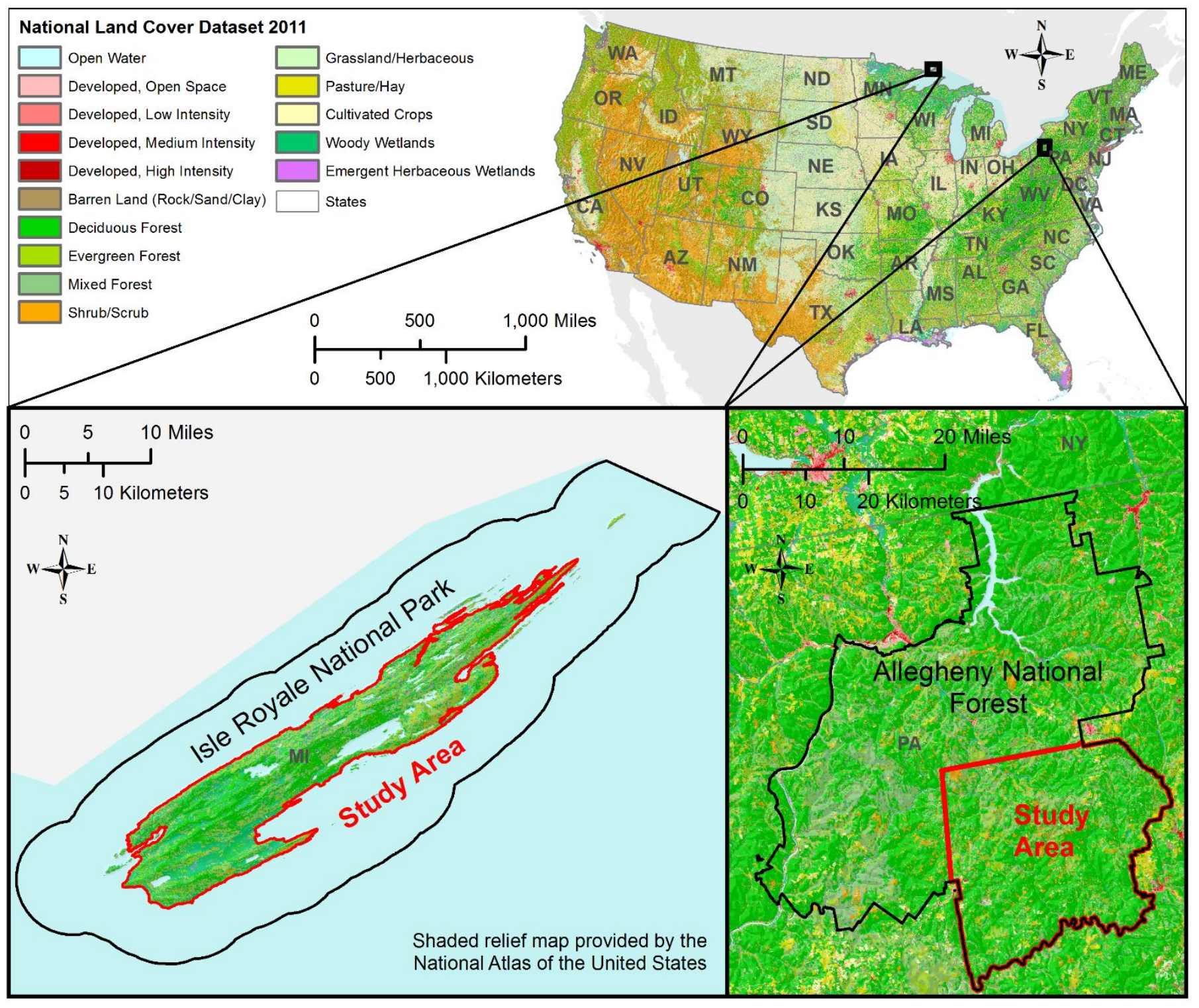

Figure 1. 


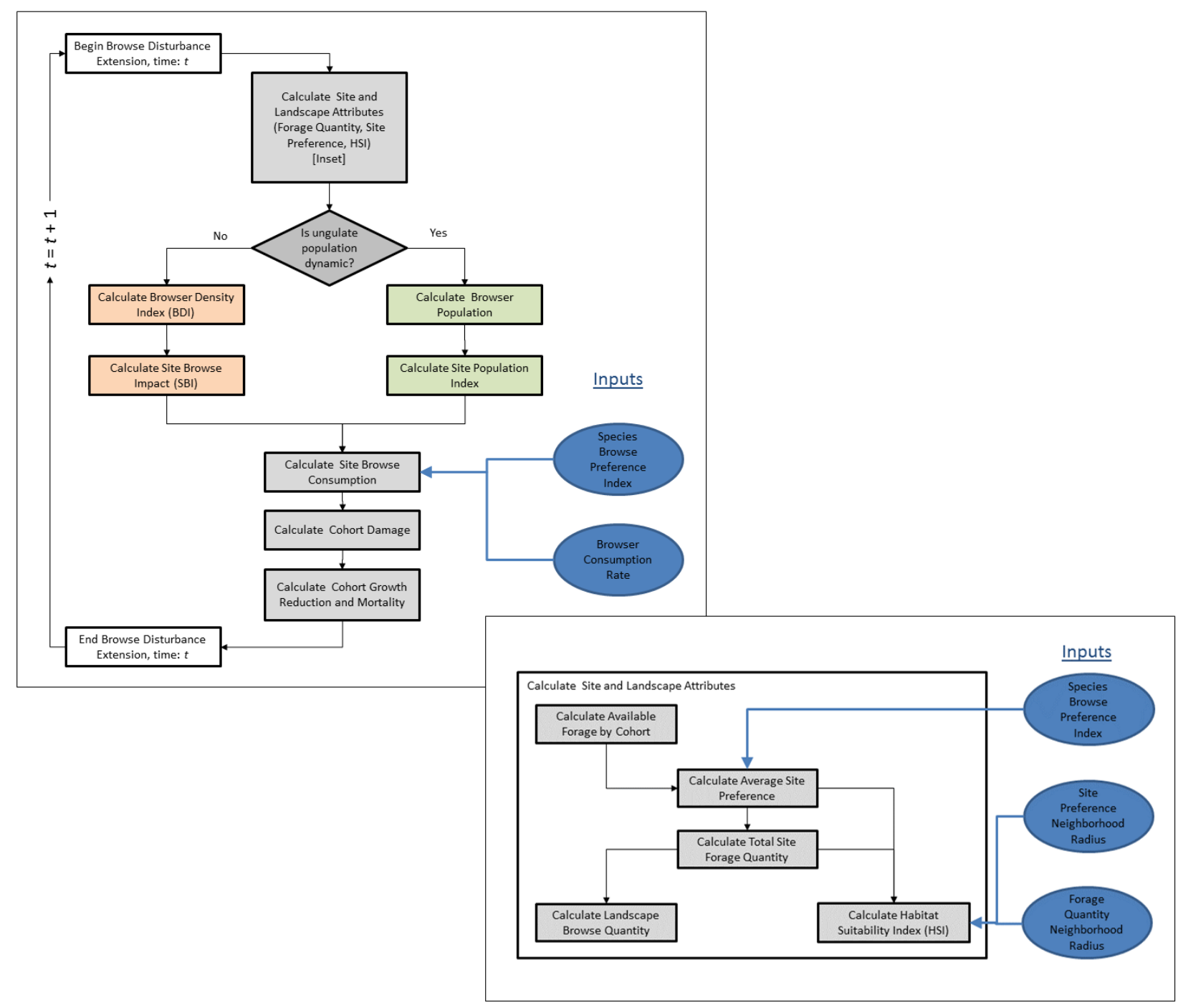

Figure 2 

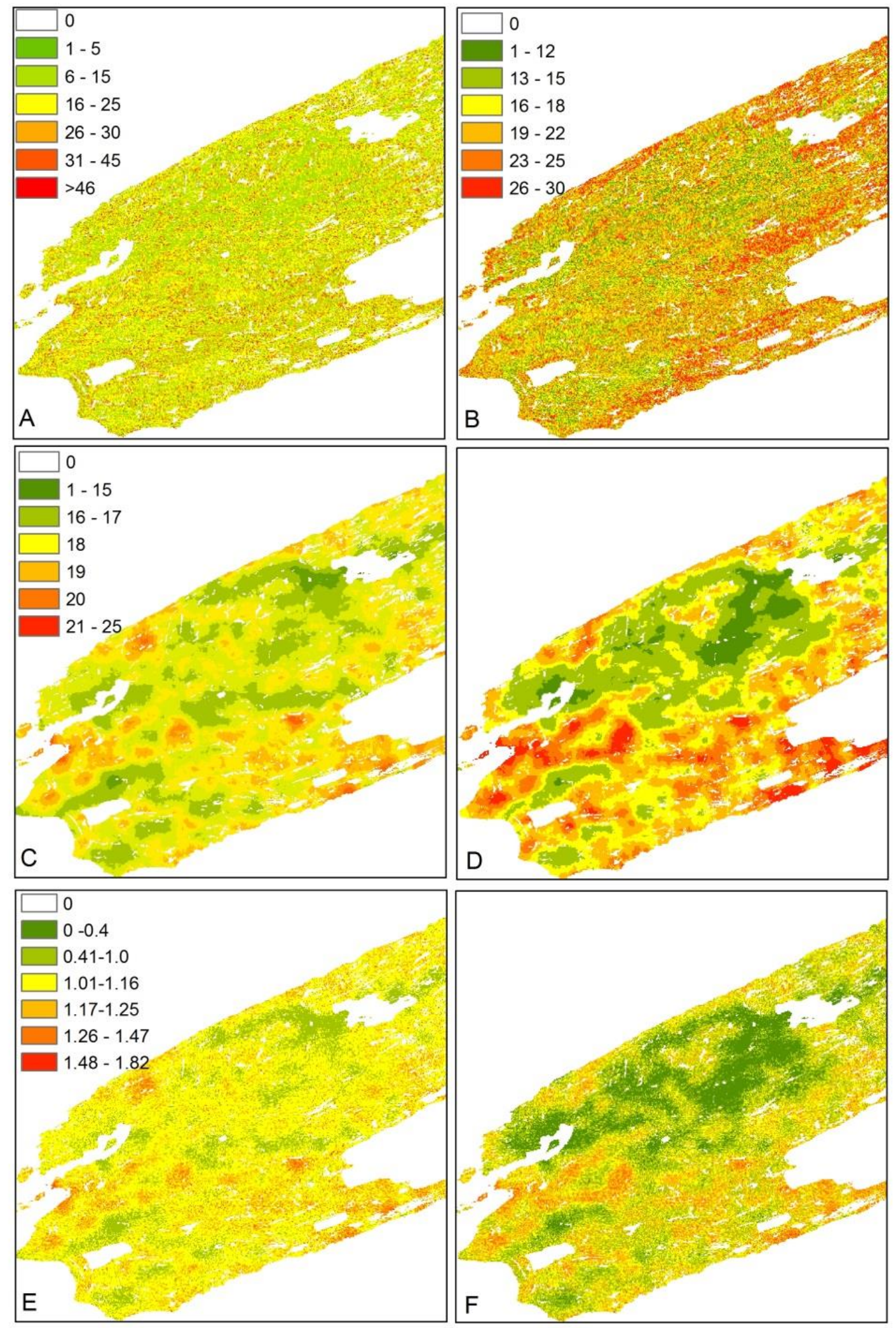

Figure 3. 

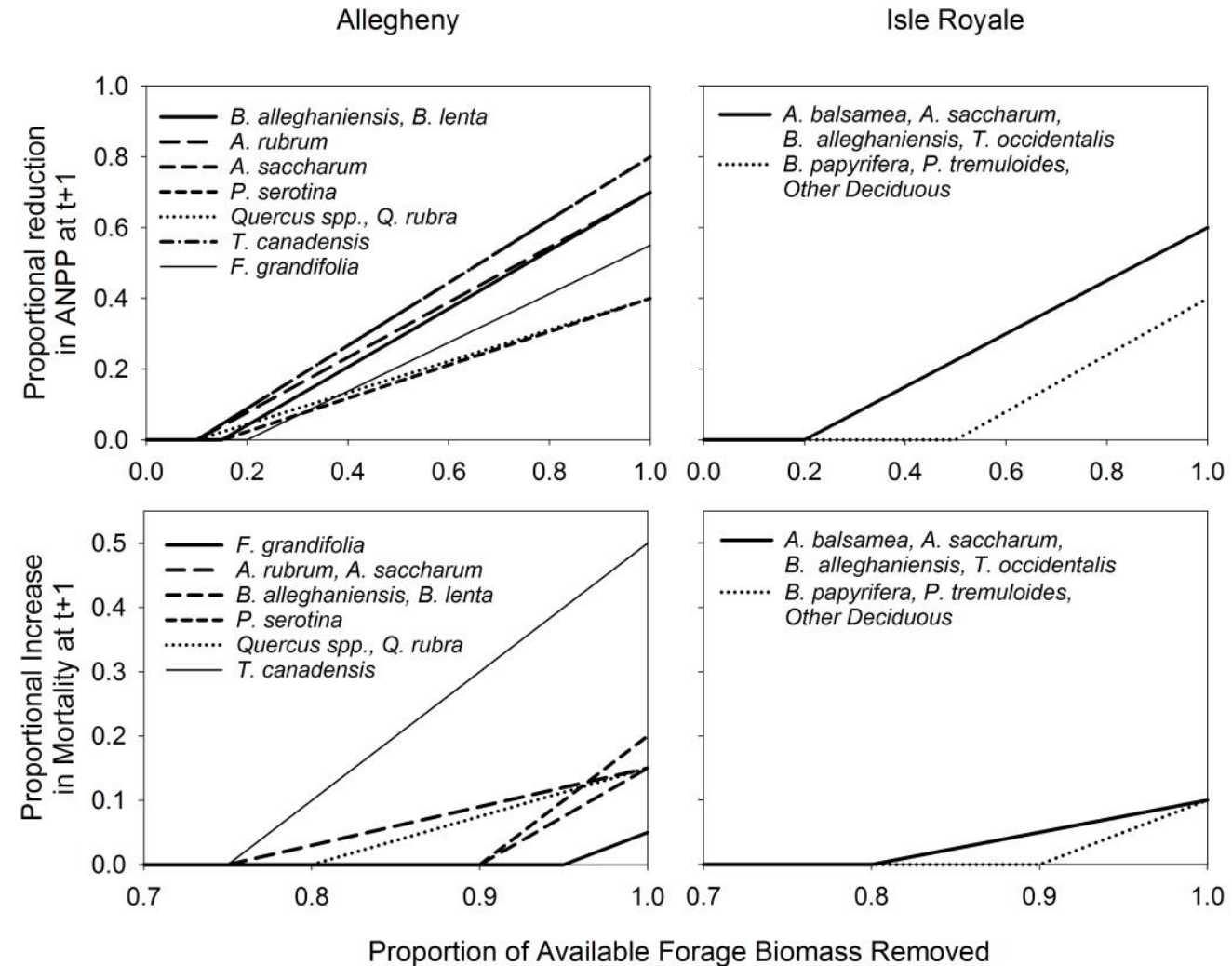

Figure 4. 

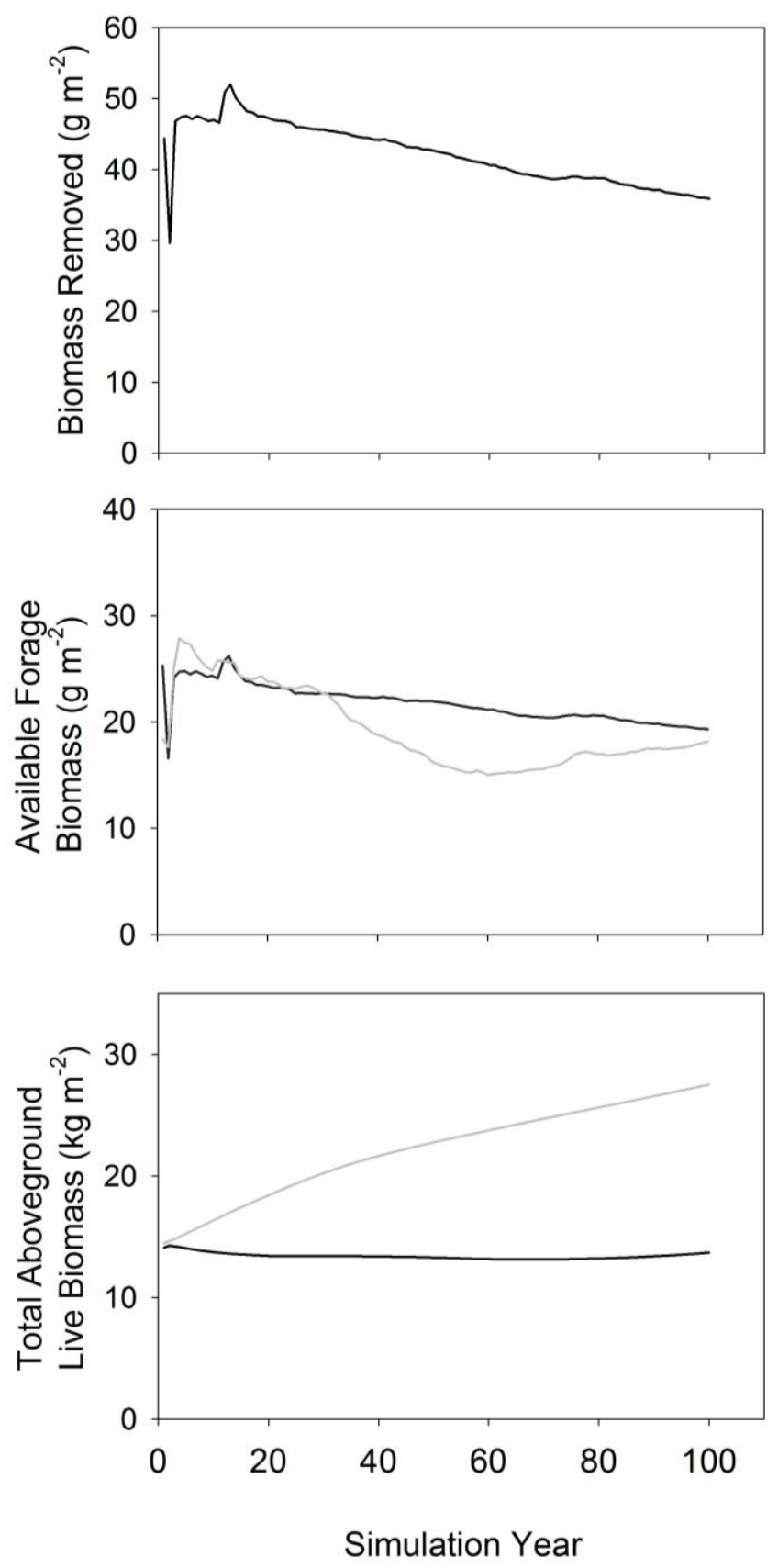

Figure 5. 


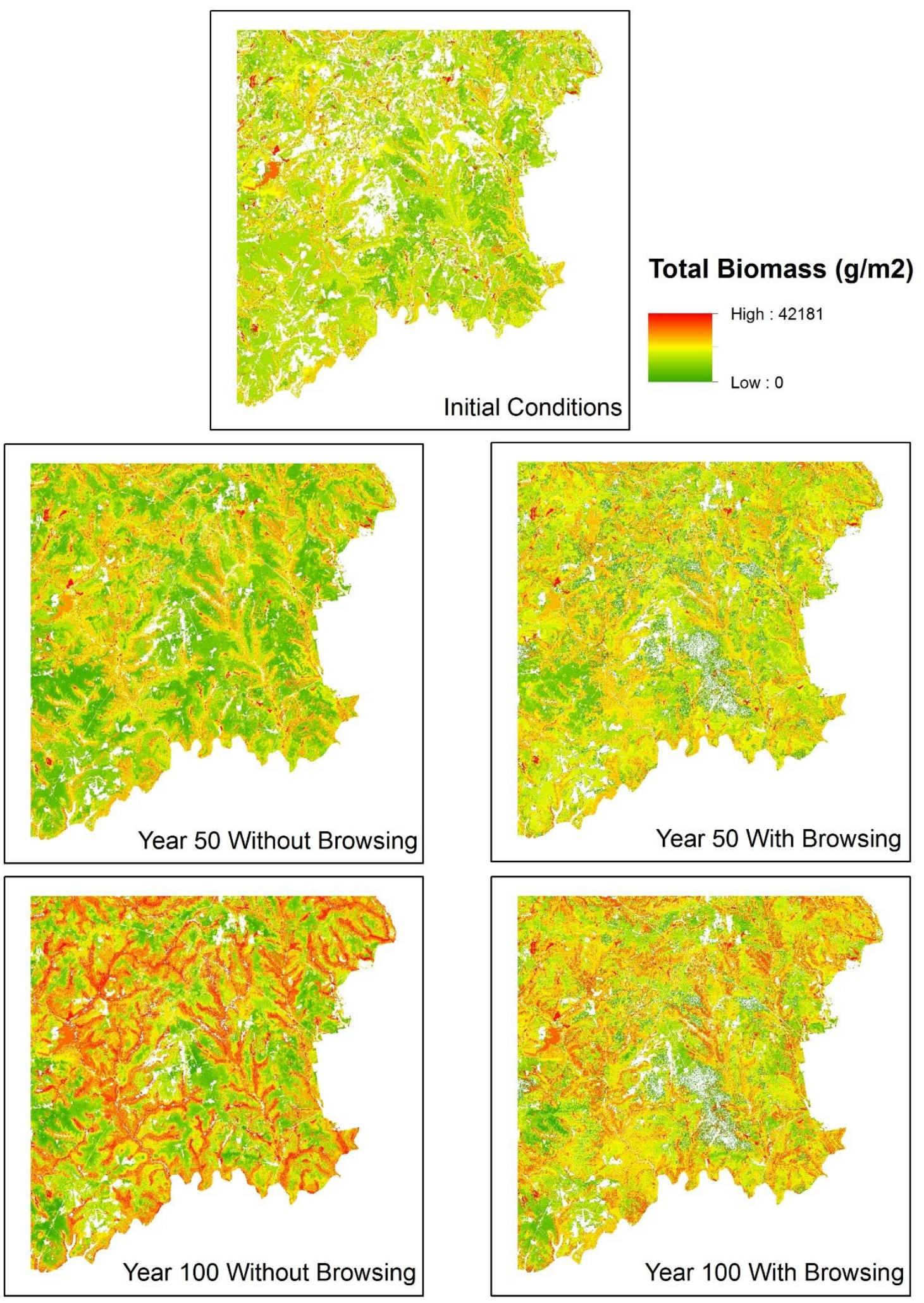

Figure 6. 


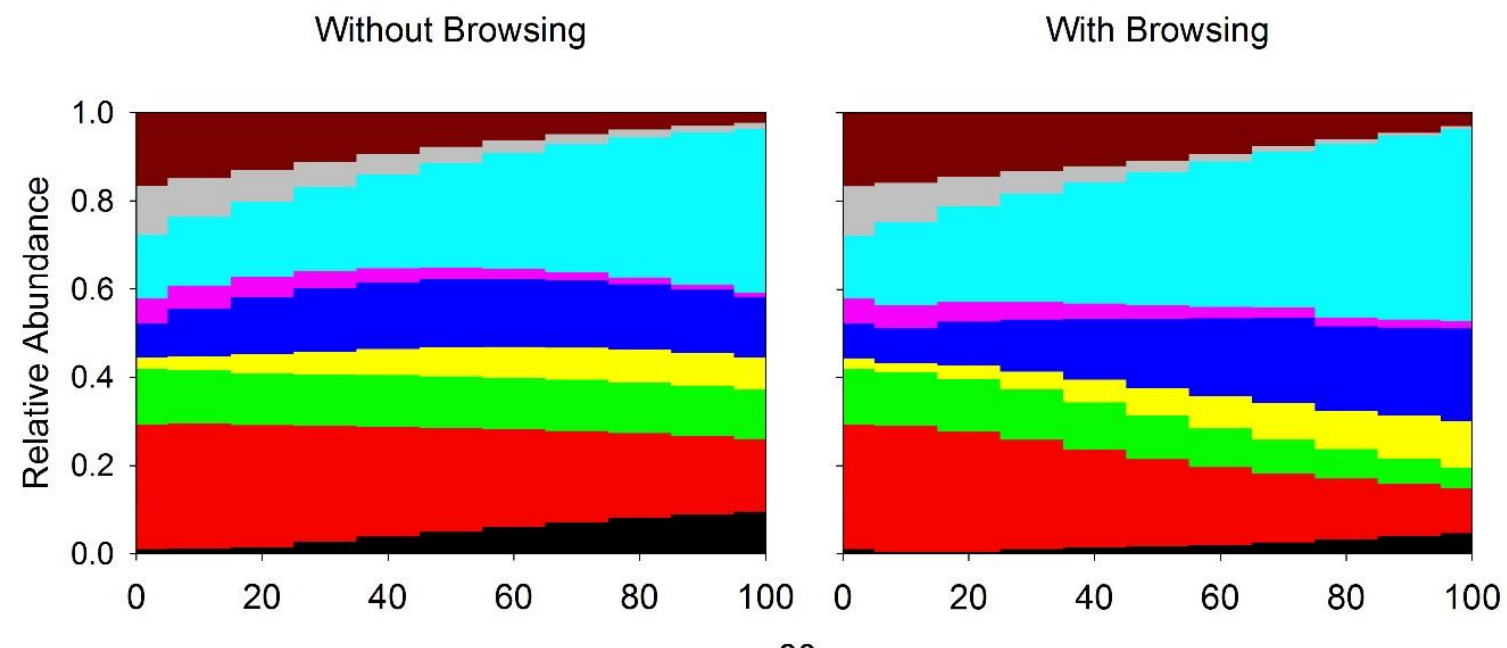

With Browsing
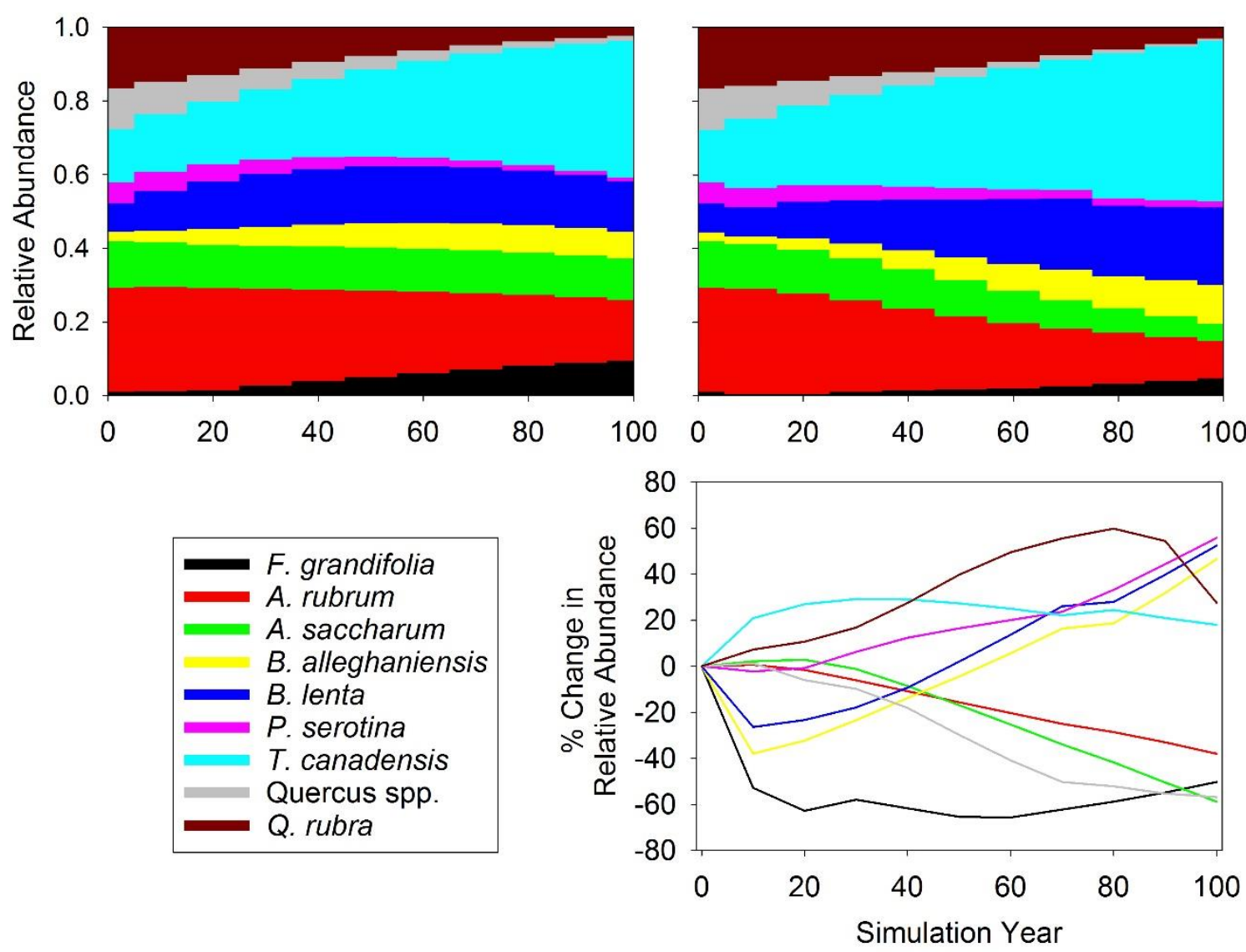

Figure 7. 

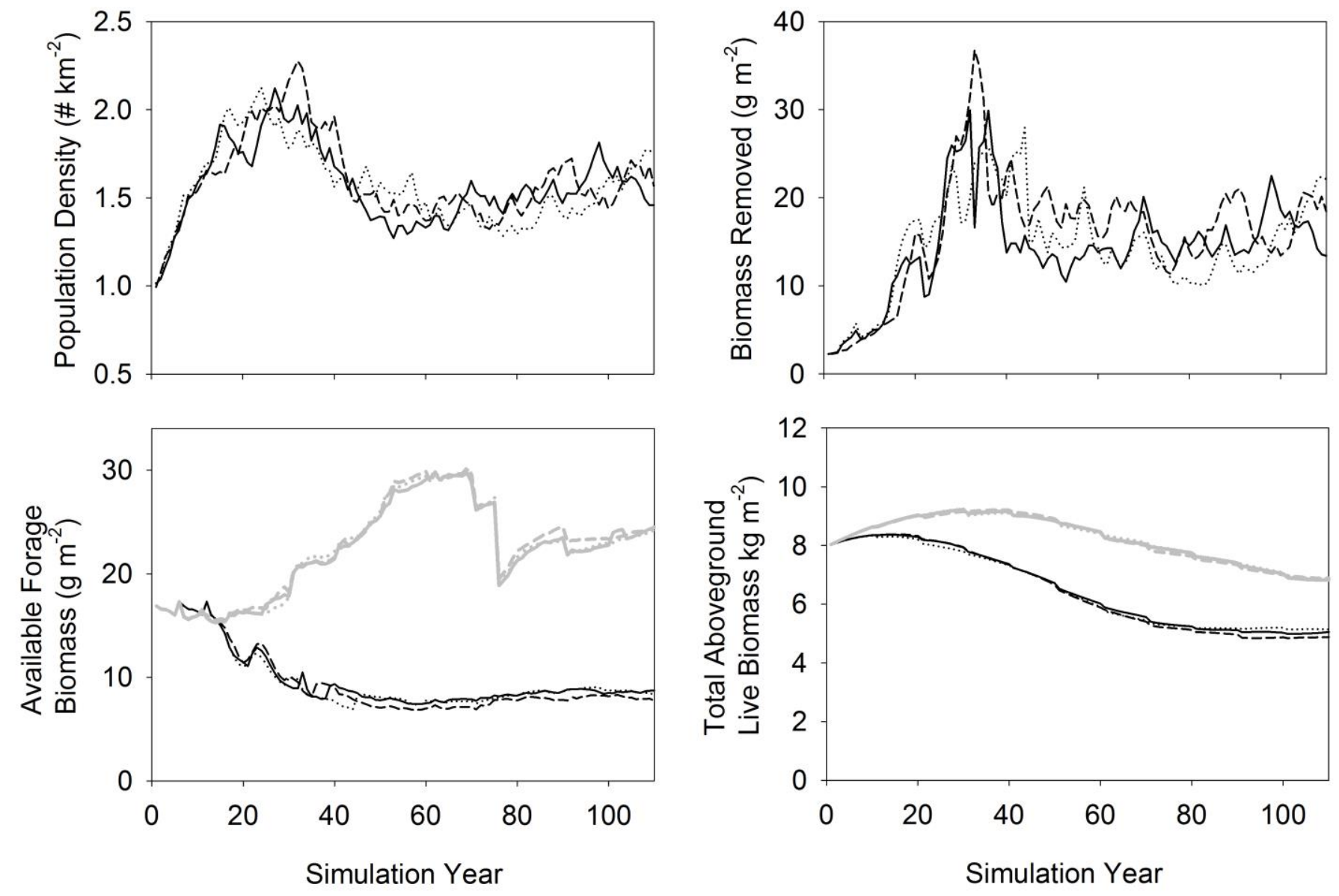

Figure 8 . 


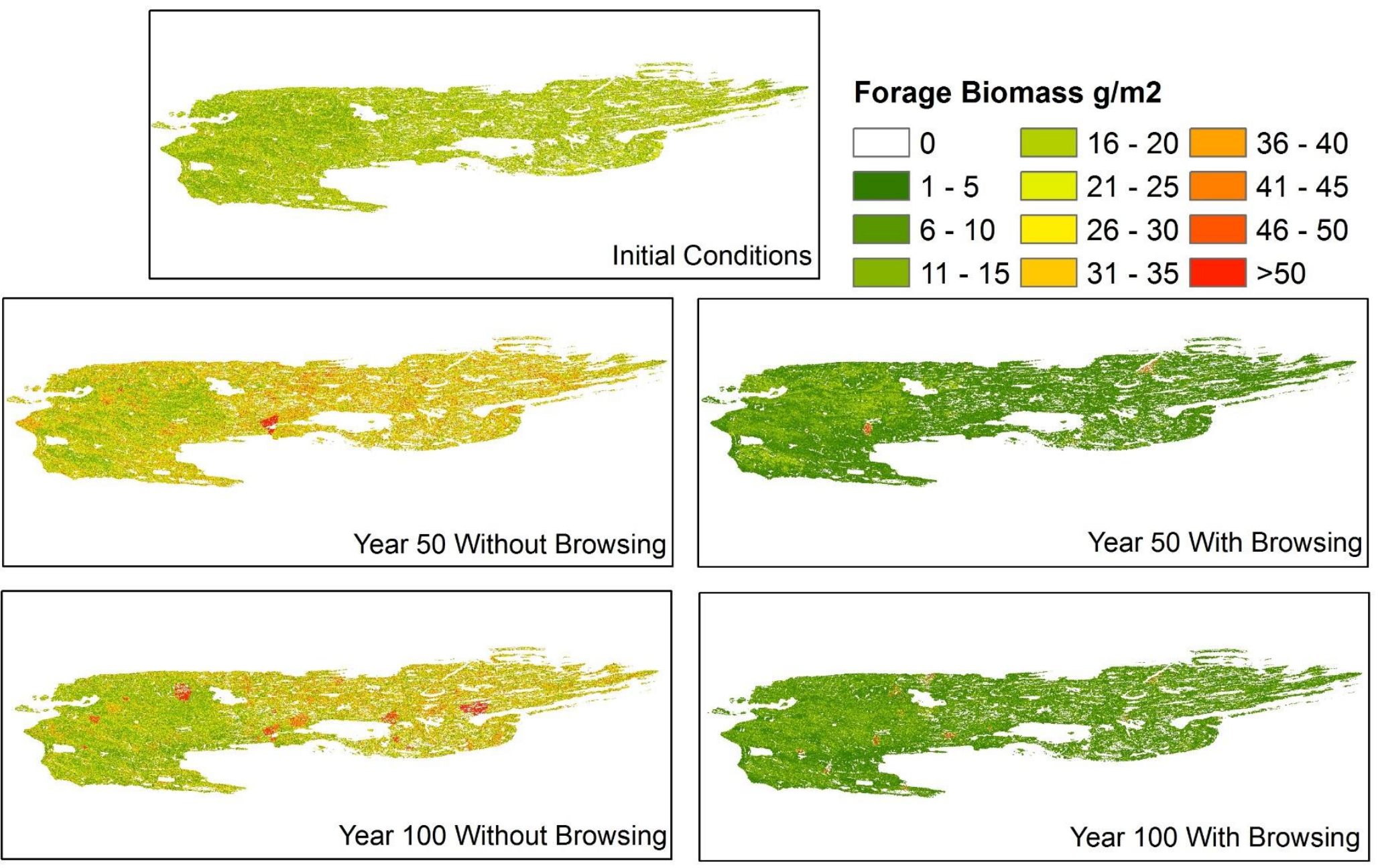

Figure 9. 
Without Browsing

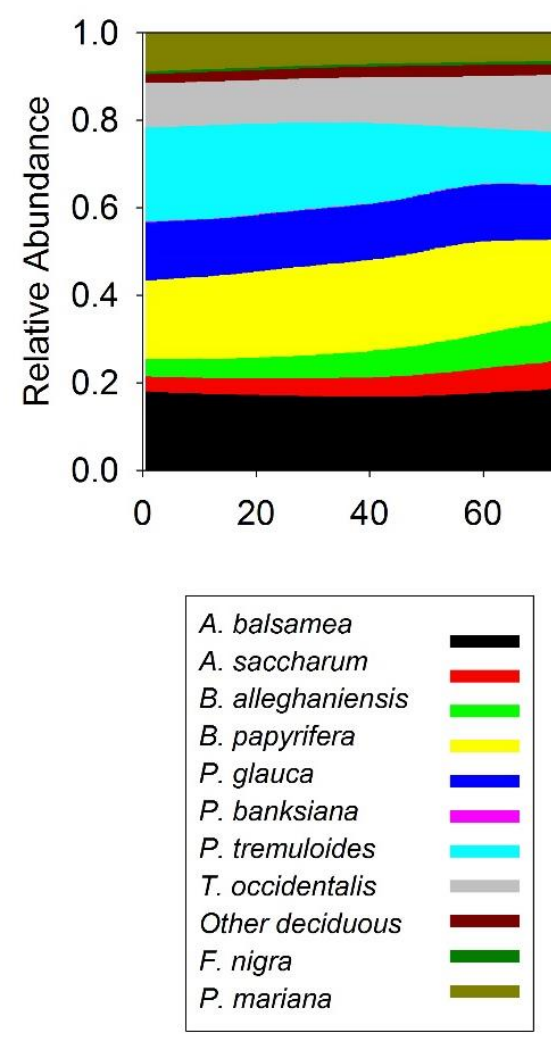

With Browsing

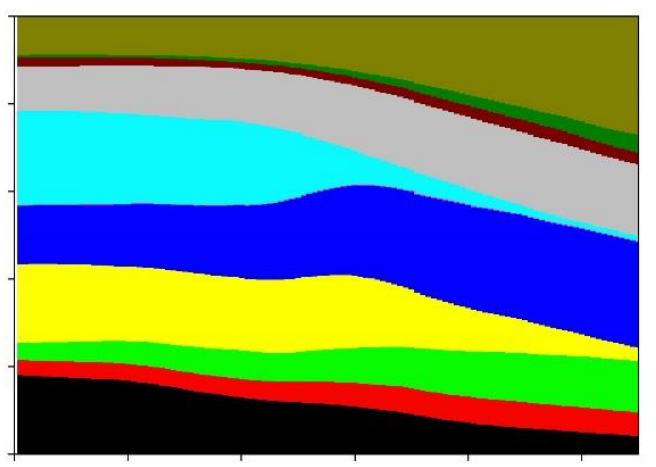

$80 \quad 100$

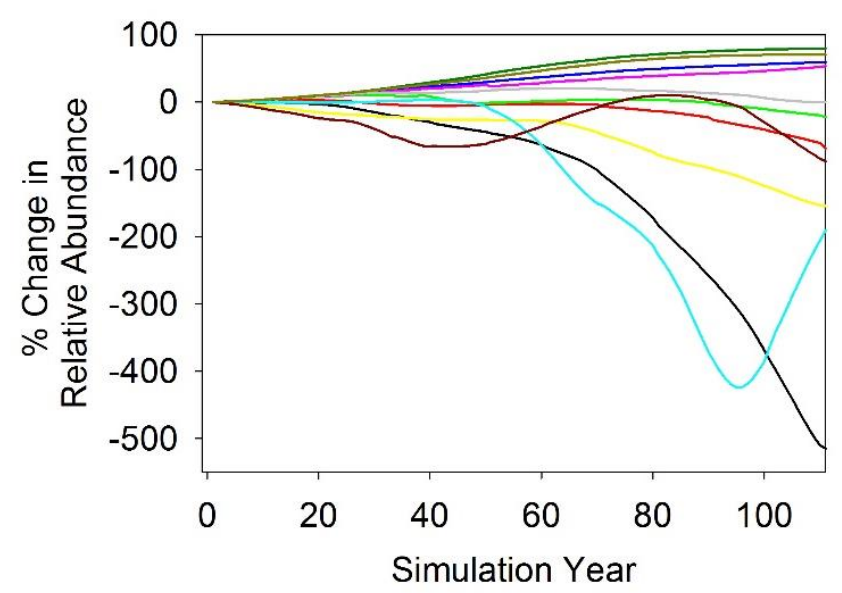

Figure 10. 
Table 1. The LANDIS-II Browse Extension requires a series of user-defined parameter estimates, which are described here. Also given are the parameter values used in model applications at Allegheny National Forest (ANF) and Isle Royale National Park (ISRO). 


\begin{tabular}{|c|c|c|c|c|c|}
\hline Component & $\begin{array}{l}\text { Variable } \\
\text { (Abbreviation) }\end{array}$ & Units & ANF & ISRO & Description \\
\hline \multirow[t]{5}{*}{$\begin{array}{l}\text { Available } \\
\text { Forage Biomass }\end{array}$} & ANPPForageProp $\mathrm{r}$ & Proportion & 0.66 & 0.66 & Proportion of ANPP that is available forage biomass \\
\hline & MinBrowsePropinReach & Proportion & 0.5 & 0.3 & $\begin{array}{l}\text { Minimum proportion of forage within reach for a } \\
\text { cohort to be considered accessible }\end{array}$ \\
\hline & BrowseBiomassThreshold & Proportion & 0.05 & 0.05 & $\begin{array}{l}\text { Proportion of ecoregion maximum biomass when a } \\
\text { cohort begins to escape browsing }\end{array}$ \\
\hline & EscapeBrowsePropLong & Proportion & 0.57 & 0.57 & $\begin{array}{l}\text { The proportion of the longevity of a species, at } \\
\text { which cohorts escape browsing }\end{array}$ \\
\hline & UseInitBiomassAsForage & $\mathrm{Y} / \mathrm{N}$ & $\mathrm{T}$ & $\mathrm{F}$ & $\begin{array}{l}\text { Use the total biomass of first-year cohorts as } \\
\text { available, F-use only a fraction of ANPP from year } \\
1 \text { to } 2 \text { as available }\end{array}$ \\
\hline \multirow[t]{3}{*}{$\begin{array}{l}\text { Browse } \\
\text { Biomass } \\
\text { Removal }\end{array}$} & SpeciesPreference & Proportion & $\begin{array}{l}\text { see table } \\
2 \mathrm{a}\end{array}$ & $\begin{array}{l}\text { see table } \\
2 b\end{array}$ & $\begin{array}{l}\text { Target proportion of available forage biomass to be } \\
\text { removed from a species, also used to rank species } \\
\text { by preference }\end{array}$ \\
\hline & ConsumptionRate & $\begin{array}{l}\mathrm{kg} / \mathrm{animal} / \\
\mathrm{yr}\end{array}$ & N/A & 2327 & Annual consumption rate per animal \\
\hline & $\begin{array}{l}\text { Browser Density Index } \\
\text { (BDI) }\end{array}$ & Proportion & 0.45 & N/A & Proportion of total available forage to remove \\
\hline \multirow[t]{4}{*}{$\begin{array}{l}\text { Effects } \\
\text { Browsing }\end{array}$} & $\begin{array}{l}\text { Growth Reduction } \\
\text { Threshold (GRT) }\end{array}$ & Proportion & $\begin{array}{l}\text { see table } \\
2 \mathrm{a}\end{array}$ & $\begin{array}{l}\text { see table } \\
2 b\end{array}$ & $\begin{array}{l}\text { Proportion of available forage biomass removed that } \\
\text { triggers a reduction in ANPP at } t+1\end{array}$ \\
\hline & $\begin{array}{l}\text { Growth Reduction } \\
\text { Maximum (GRM) }\end{array}$ & Proportion & $\begin{array}{l}\text { see table } \\
2 \mathrm{a}\end{array}$ & $\begin{array}{l}\text { see table } \\
2 \mathrm{~b}\end{array}$ & $\begin{array}{l}\text { Maximum reduction in ANPP at } t+1 \text { at } 100 \% \\
\text { removal of available forage biomass }\end{array}$ \\
\hline & Mortality Threshold (MT) & Proportion & $\begin{array}{l}\text { see table } \\
2 \mathrm{a}\end{array}$ & $\begin{array}{l}\text { see table } \\
2 \mathrm{~b}\end{array}$ & $\begin{array}{l}\text { Proportion of available forage biomass removed that } \\
\text { triggers an increase in probability of mortality at } t+1\end{array}$ \\
\hline & Mortality Maximum (MM) & Proportion & $\begin{array}{l}\text { see table } \\
2 \mathrm{a}\end{array}$ & $\begin{array}{l}\text { see table } \\
2 b\end{array}$ & $\begin{array}{l}\text { Maximum increase in the probability of mortality at } \\
\mathrm{t}+1 \text { at } 100 \% \text { removal of available forage biomass }\end{array}$ \\
\hline \multirow[t]{2}{*}{$\begin{array}{l}\text { Population } \\
\text { Density }\end{array}$} & Initial Population Size $\left(\mathrm{N}_{\text {init }}\right)$ & \# animals & N/A & $\begin{array}{l}450(\sim 1 \\
\left.\text { per } \mathrm{km}^{2}\right)\end{array}$ & Initial population size, by population zone \\
\hline & Population Growth Rate (R) & Rate & N/A & $\begin{array}{l}0.15- \\
0.25\end{array}$ & $\begin{array}{l}\text { Min and Max population growth rate, by population } \\
\text { zone }\end{array}$ \\
\hline
\end{tabular}




\begin{tabular}{|c|c|c|c|c|c|}
\hline $\begin{array}{l}\text { Miscellaneous } \\
\text { (M) }\end{array}$ & mortality & Rate & N/A & $0.0-0.1$ & Min and Max mortality rate, by population zone \\
\hline Predation $(\mathrm{P})$ & & Rate & N/A & $0.03-0.1$ & Min and Max predation rate, by population zone \\
\hline Harvest $(\mathrm{H})$ & & Rate & N/A & $0.0-0.0$ & Min and Max harvest rate, by population zone \\
\hline
\end{tabular}

Habitat

Suitability/Pop

ulation

ForageQuantity

$\mathrm{Y} / \mathrm{N}, \mathrm{m}$

Y, 321

N

Utilize available forage biomass in calculating HSI,

Distribution

\begin{tabular}{lllll} 
SitePreference & Y/N, m & Y, 1284 & Y, 1500 & $\begin{array}{l}\text { Utilize site preference in calculating HSI, optional } \\
\text { moving window size } \\
\text { include non-forage species in calculations of site } \\
\text { preference }\end{array}$ \\
\hline
\end{tabular}


Tables 2 A and B: Browse disturbance parameters used in LANDIS-II simulations for the Allegheny National Forest (A, ANF), and Isle Royale National Park (B, ISRO). Preference values are used to rank species according to their preference by the herbivore and define a target proportion of available forage biomass to be removed at a site during a given time step. Growth reduction and mortality parameters define a threshold proportion of available forage biomass removed that triggers a growth or mortality response, and a maximum growth or mortality response when $100 \%$ of available forage biomass is removed. See Figure 5 for graphic representation of the growth and mortality parameters.

\begin{tabular}{|c|c|c|c|c|c|}
\hline \multirow{2}{*}{$\begin{array}{l}\text { A. } \\
\text { Species }\end{array}$} & \multirow[b]{2}{*}{ Preference } & \multicolumn{2}{|c|}{ Growth Reduction } & \multicolumn{2}{|l|}{ Mortality } \\
\hline & & Threshold & $\operatorname{Max}$ & Threshold & Max \\
\hline F. grandifolia $^{1,3,5}$ & 0.330 & 0.2 & 0.55 & 0.95 & 0.05 \\
\hline A. rubrum $^{1,3,5}$ & 0.600 & 0.10 & 0.7 & 0.75 & 0.15 \\
\hline A. saccharum ${ }^{1,3,5}$ & 0.495 & 0.10 & 0.8 & 0.75 & 0.15 \\
\hline B. alleghaniensis ${ }^{1,3,4,5}$ & 0.400 & 0.15 & 0.7 & 0.90 & 0.15 \\
\hline B. lenta ${ }^{1,3,5}$ & 0.400 & 0.15 & 0.7 & 0.90 & 0.15 \\
\hline P. serotina ${ }^{1,3,5}$ & 0.165 & 0.15 & 0.4 & 0.90 & 0.20 \\
\hline General Quercus ${ }^{1,4,5}$ & 0.600 & 0.10 & 0.4 & 0.80 & 0.15 \\
\hline Q. rubra $^{1,5}$ & 0.600 & 0.10 & 0.4 & 0.80 & 0.15 \\
\hline T. canadensis $^{1,2,5}$ & 0.495 & 0.10 & 0.8 & 0.75 & 0.5 \\
\hline
\end{tabular}

1, Latham et al (2005); 2, Anderson and Loucks (1979); 3, Marquis (1981); 4, Rooney and Waller (2003); 5, Russell et al. (2001)

\begin{tabular}{|c|c|c|c|c|c|}
\hline \multirow{2}{*}{$\begin{array}{l}\text { B. } \\
\text { Species }\end{array}$} & \multirow[b]{2}{*}{ Preference } & \multicolumn{2}{|c|}{ Growth Reduction } & \multicolumn{2}{|l|}{ Mortality } \\
\hline & & Threshold & Max & Threshold & $\operatorname{Max}$ \\
\hline A. balsamea ${ }^{1,2,4,6}$ & 0.15 & 0.2 & 0.6 & 0.8 & 0.1 \\
\hline A. saccharum ${ }^{2,3,6}$ & 0.15 & 0.2 & 0.6 & 0.8 & 0.1 \\
\hline B. alleghaniensis ${ }^{2,3,6}$ & 0.15 & 0.2 & 0.6 & 0.8 & 0.1 \\
\hline B. papyrifera ${ }^{2,5,6}$ & 0.25 & 0.5 & 0.4 & 0.9 & 0.1 \\
\hline F. nigra ${ }^{1,2,6}$ & 0 & 0 & 1 & 0.8 & 0.1 \\
\hline Other Deciduous $1,2,6$ & 0.25 & 0.5 & 0.4 & 0.9 & 0.1 \\
\hline P. banksiana ${ }^{1,2,6}$ & 0 & 0 & 1 & 0.8 & 0.1 \\
\hline P. glauca $^{1,2,6}$ & 0 & 0 & 1 & 0.8 & 0.1 \\
\hline P. mariana ${ }^{1,2,6}$ & 0 & 0 & 1 & 0.8 & 0.1 \\
\hline P. tremuloides ${ }^{1,2,3,6}$ & 0.30 & 0.5 & 0.4 & 0.9 & 0.1 \\
\hline T. occidentalis ${ }^{1,2,6,7}$ & 0.05 & 0.2 & 0.6 & 0.8 & 0.1 \\
\hline
\end{tabular}

1, Hodgson (2010); 2, Risenhoover (1987); 3, Sell (2007); 4, De Jager et al. (2009); 5, De Jager and Pastor (2008); 6, Murie (1934); 7, Parikh (2015) 